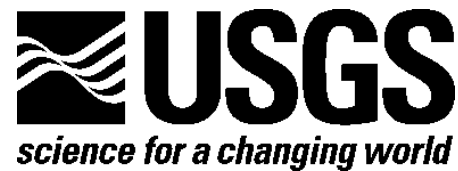

\title{
A Probabilistic Assessment Methodology for the Evaluation of Geologic Carbon Dioxide Storage
}

By Sean T. Brennan, Robert C. Burruss, Matthew D. Merrill, Philip A. Freeman, and Leslie F. Ruppert

Open-File Report 2010-1127

U.S. Department of the Interior

U.S. Geological Survey 


\section{U.S. Department of the Interior \\ KEN SALAZAR, Secretary}

\section{U.S. Geological Survey \\ Marcia K. McNutt, Director}

U.S. Geological Survey, Reston, Virginia: 2010

For product and ordering information:

World Wide Web: http://www.usgs.gov/pubprod

Telephone: 1-888-ASK-USGS

For more information on the USGS-the Federal source for science about the Earth,

its natural and living resources, natural hazards, and the environment:

World Wide Web: http://www.usgs.gov

Telephone: 1-888-ASK-USGS

Suggested citation:

Brennan, S.T., Burruss, R.C., Merrill, M.D., Freeman, P.A., and Ruppert, L.F., 2010, A probabilistic assessment methodology for the evaluation of geologic carbon dioxide storage: U.S. Geological Survey Open-File Report 2010-1127, 31 p., available only at http://pubs.usgs.gov/of/2010/1127.

Any use of trade, product, or firm names is for descriptive purposes only and does not imply endorsement by the U.S. Government.

Although this report is in the public domain, permission must be secured from the individual copyright owners to reproduce any copyrighted material contained within this report. 


\section{Contents}

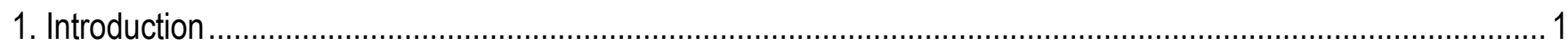

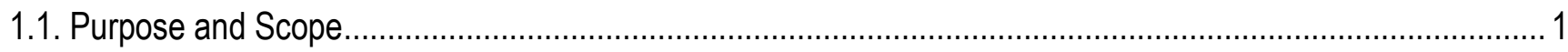

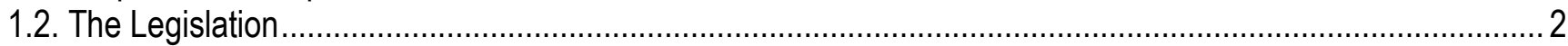

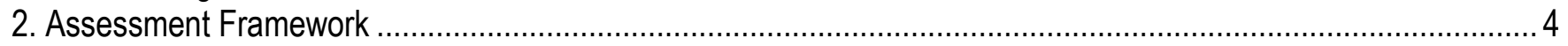

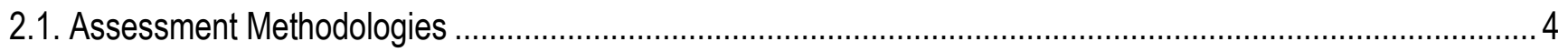

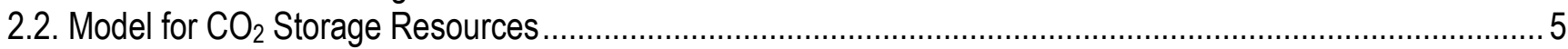

2.3. Geologic Framework ………............................................................................................

2.3.1. Storage Assessment Unit (SAU) - Storage Formation .................................................................

2.3.2. Storage Assessment Unit (SAU) - Seal Formation ....................................................................... 8

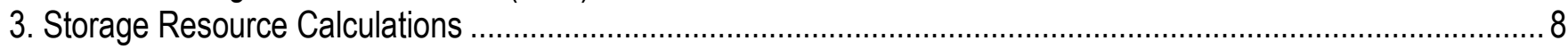

3.1. Storage Formation Pore Volume .................................................................................................

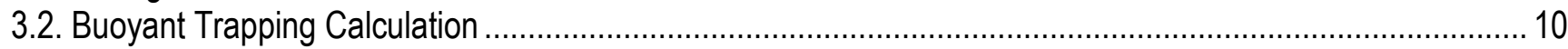

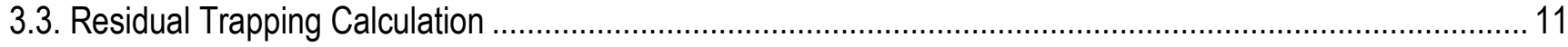

3.4. Technically Accessible Storage Resource .................................................................................... 13

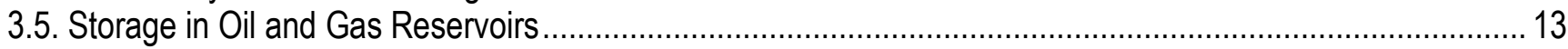

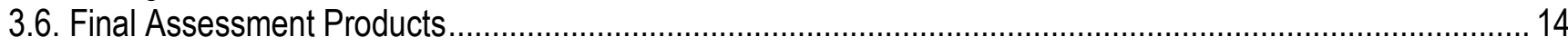

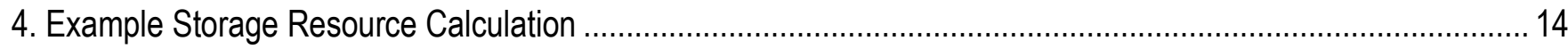

4.1. Data Sources ………………………………… 14

4.2. Example Storage Assessment Unit............................................................................................. 15

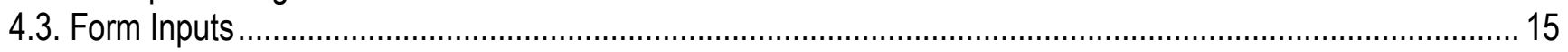

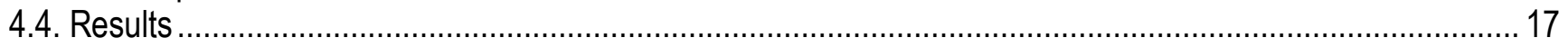

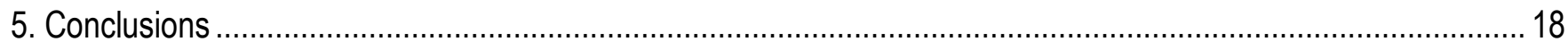

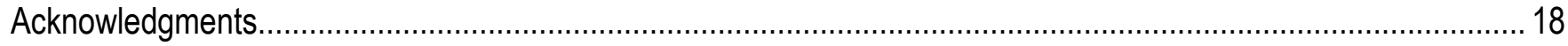

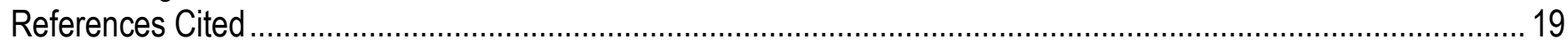

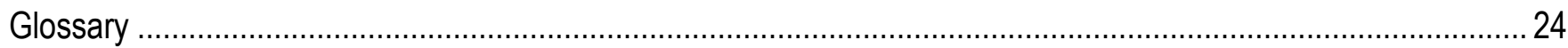

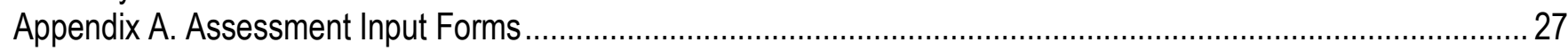

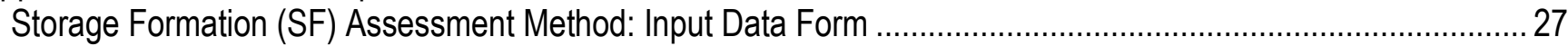

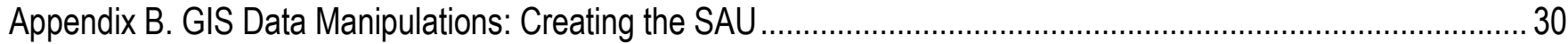

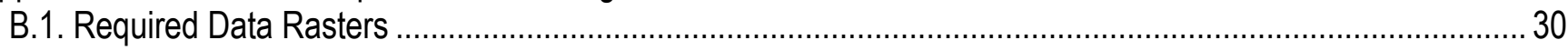

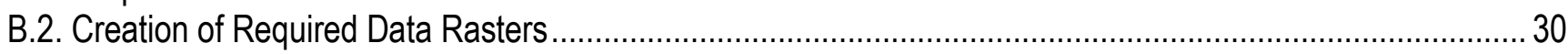

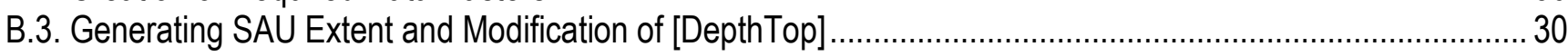

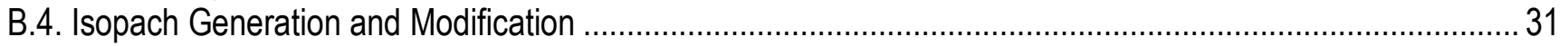

\section{Figures}

1. A resource triangle depicting the relation between buoyant and residual storage resources that schematically illustrates the relation between uncertainties in knowledge of the resource and the relative volume of the resource.

2. A schematic cross section through a storage assessment unit illustrating the relation between buoyant and residual trapping styles in the storage formation.

3. Flow diagram of key steps for calculating buoyant trapping storage resources and residual trapping storage resources. 
4. Map showing the example of the Tensleep Sandstone storage assessment unit in the Wind River Basin, Wyoming.

\section{Tables}

1. Storage resource values of $\mathrm{CO}_{2}$ for five different classifications within the Tensleep Sandstone storage assessment unit.

2. Storage resource values of $\mathrm{CO}_{2}$ for petroleum reservoirs in the Tensleep Sandstone storage assessment unit. 


\section{Conversion Factors}

\begin{tabular}{|c|c|c|}
\hline Multiply & By & To obtain \\
\hline \multicolumn{3}{|c|}{ Length } \\
\hline inch (in.) & 2.54 & centimeter $(\mathrm{cm})$ \\
\hline foot (ft) & 0.3048 & meter $(\mathrm{m})$ \\
\hline mile (mi) & 1.609 & kilometer (km) \\
\hline meter (m) & 3.281 & foot $(\mathrm{ft})$ \\
\hline kilometer (km) & 0.6214 & mile (mi) \\
\hline \multicolumn{3}{|c|}{ Area } \\
\hline square inch $\left(\mathrm{in}^{2}\right)$ & 6.452 & square centimeter $\left(\mathrm{cm}^{2}\right)$ \\
\hline square foot $\left(\mathrm{ft}^{2}\right)$ & 0.09290 & square meter $\left(\mathrm{m}^{2}\right)$ \\
\hline acre & 0.4047 & hectare (ha) \\
\hline acre & 0.004047 & square kilometer $\left(\mathrm{km}^{2}\right)$ \\
\hline square meter $\left(\mathrm{m}^{2}\right)$ & 0.0002471 & acre \\
\hline \multicolumn{3}{|c|}{ Volume } \\
\hline gallon (gal) & 3.785 & liter $(\mathrm{L})$ \\
\hline barrel (bbl), (petroleum, 1 barrel=42 gal) & 0.1590 & cubic meter $\left(\mathrm{m}^{3}\right)$ \\
\hline cubic foot $\left(\mathrm{ft}^{3}\right)$ & 0.02832 & cubic meter $\left(\mathrm{m}^{3}\right)$ \\
\hline 1,000 cubic feet (MCF) & 28.32 & cubic meter $\left(\mathrm{m}^{3}\right)$ \\
\hline liter $(\mathrm{L})$ & 0.2642 & gallon (gal) \\
\hline cubic meter $\left(\mathrm{m}^{3}\right)$ & 6.290 & barrel (petroleum, 1 barrel $=42 \mathrm{gal})$ \\
\hline \multicolumn{3}{|c|}{ Mass } \\
\hline pound, avoirdupois (lb) & 0.4536 & kilogram $(\mathrm{kg})$ \\
\hline ton, short $(2,000 \mathrm{lb})$ & 0.9072 & megagram $(\mathrm{Mg})$ \\
\hline ton, long $(2,240 \mathrm{lb})$ & 1.016 & megagram $(\mathrm{Mg})$ \\
\hline milligram (mg) & 0.00003527 & ounce, avoirdupois (oz) \\
\hline $\operatorname{gram}(\mathrm{g})$ & 0.03527 & ounce, avoirdupois (oz) \\
\hline kilogram $(\mathrm{kg})$ & 2.205 & pound avoirdupois (lb) \\
\hline megagram $(\mathrm{Mg})=1$ metric ton $(\mathrm{t})(1,000 \mathrm{~kg})$ & 1.102 & ton, short $(2,000 \mathrm{lb})$ \\
\hline megagram (Mg) & 0.9842 & ton, long $(2,240 \mathrm{lb})$ \\
\hline million metric tons & 1.102 & million short tons \\
\hline \multicolumn{3}{|c|}{ Pressure } \\
\hline atmosphere, standard (atm) & 101.3 & kilopascal (kPa) \\
\hline bar & 100 & kilopascal $(\mathrm{kPa})$ \\
\hline pound-force per square inch (lbf/in ${ }^{2}$ or psi) & 6.895 & kilopascal $(\mathrm{kPa})$ \\
\hline kilopascal (kPa) & 0.009869 & atmosphere, standard (atm) \\
\hline
\end{tabular}




\begin{tabular}{|c|c|c|}
\hline Multiply & By & To obtain \\
\hline kilopascal $(\mathrm{kPa})$ & 0.01 & bar \\
\hline kilopascal (kPa) & 0.2961 & inch of mercury at $60^{\circ} \mathrm{F}$ (in $\mathrm{Hg}$ ) \\
\hline kilopascal (kPa) & 0.1450 & pound-force per square inch $\left(\mathrm{lbf} / \mathrm{in}^{2}\right)$ \\
\hline megapascal (MPa) & 145 & pound-force per square inch $\left(\mathrm{lbf} / \mathrm{in}^{2}\right)$ \\
\hline \multicolumn{3}{|c|}{ Pressure gradient } \\
\hline $\begin{array}{l}\text { pound-force per square inch per foot } \\
\left(\mathrm{lb} / \mathrm{in}^{2} / \mathrm{ft} \text { or psi/ft) }\right.\end{array}$ & 22.62 & kilopascal per meter $(\mathrm{kPa} / \mathrm{m})$ \\
\hline \multicolumn{3}{|c|}{ Density } \\
\hline pound per cubic foot $\left(\mathrm{lb} / \mathrm{ft}^{3}\right)$ & 16.02 & kilogram per cubic meter $\left(\mathrm{kg} / \mathrm{m}^{3}\right)$ \\
\hline pound per cubic foot $\left(\mathrm{lb} / \mathrm{ft}^{3}\right)$ & 0.01602 & gram per cubic centimeter $\left(\mathrm{g} / \mathrm{cm}^{3}\right)$ \\
\hline kilogram per cubic meter $\left(\mathrm{kg} / \mathrm{m}^{3}\right)$ & 0.06242 & pound per cubic foot $\left(\mathrm{lb} / \mathrm{ft}^{3}\right)$ \\
\hline gram per cubic centimeter $\left(\mathrm{g} / \mathrm{cm}^{3}\right)$ & 62.4220 & pound per cubic foot $\left(\mathrm{lb} / \mathrm{ft}^{3}\right)$ \\
\hline \multicolumn{3}{|c|}{ Electric power } \\
\hline megawatt electrical (MWe) & $0,000,000$ & joule per hour $(\mathrm{J} / \mathrm{hr})$ \\
\hline \multicolumn{3}{|c|}{ Hydraulic conductivity } \\
\hline meters per second $(\mathrm{m} / \mathrm{s})$ & 3.281 & foot per second (ft/s) \\
\hline \multicolumn{3}{|c|}{ Hydraulic diffusivity } \\
\hline square meter per second $\left(\mathrm{m}^{2} / \mathrm{s}\right)$ & 10.76 & square foot per second $\left(\mathrm{ft}^{2} / \mathrm{s}\right)$ \\
\hline $\begin{array}{l}\text { Temperature in degrees Celsius }\left({ }^{\circ} \mathrm{C}\right) \mathrm{m} \\
{ }^{\circ} \mathrm{F}=\left(1.8 \times{ }^{\circ} \mathrm{C}\right)+32 \\
\text { Temperature in degrees Fahrenheit }\left({ }^{\circ} \mathrm{F}\right. \\
{ }^{\circ} \mathrm{C}=\left({ }^{\circ} \mathrm{F}-32\right) / 1.8 \\
\text { Concentrations of chemical constituen }\end{array}$ & $\begin{array}{l}\text { rees Fahren } \\
\text { degrees Cel }\end{array}$ & $\begin{array}{l}\left.\text { ( }{ }^{\circ} \mathrm{F}\right) \text { as follows: } \\
\left({ }^{\circ} \mathrm{C}\right) \text { as follows: }\end{array}$ \\
\hline
\end{tabular}




\section{Abbreviations, Acronyms, and Symbols}

\begin{tabular}{|c|c|}
\hline$A_{S F}$ & area of the storage formation \\
\hline $\mathrm{AU}$ & assessment unit (NOGA) \\
\hline bbl & petroleum barrel or barrels \\
\hline $\mathrm{B}_{\mathrm{PV}}$ & buoyant trapping pore volume; see glossary \\
\hline $\mathrm{B}_{\mathrm{SE}}$ & buoyant trapping storage efficiency; see glossary \\
\hline $\mathrm{B}_{S R}$ & buoyant trapping storage resource; see glossary \\
\hline Bsv & buoyant trapping storage volume; see glossary \\
\hline BOE & barrels of oil equivalent; see glossary \\
\hline $\mathrm{CO}_{2}$ & carbon dioxide \\
\hline $\mathrm{D}$ & Darcy \\
\hline DOE & U.S. Department of Energy \\
\hline EISA & Energy Independence and Security Act \\
\hline EPA & U.S. Environmental Protection Agency \\
\hline FVF & formation volume factor \\
\hline FVFs & formation volume factors \\
\hline $\mathrm{FVF}_{\mathrm{GAS}}$ & formation volume factor for gas \\
\hline FVFoll & formation volume factor for oil and natural gas liquids \\
\hline GIS & geographic information system \\
\hline GOR & gas:oil ratio; see glossary \\
\hline $\mathrm{k}$ & permeability; see glossary \\
\hline $\mathrm{KR}$ & known recovery production volumes; see glossary \\
\hline $\mathrm{KR}_{\mathrm{GAS}}$ & known recovery production volumes of gas \\
\hline $\mathrm{KR}_{\mathrm{NGL}}$ & known recovery production volumes of natural gas liquids \\
\hline KRoIL & known recovery production volumes of oil \\
\hline $\mathrm{KR}_{\mathrm{RES}}$ & known recovery production volumes converted to volumes at reservoir conditions \\
\hline $\mathrm{KRR}_{\mathrm{SR}}$ & known recovery replacement storage resource; see glossary \\
\hline $\mathrm{mD}$ & millidarcy \\
\hline MMbbl & million barrels \\
\hline MMBOE & million barrels of oil equivalent \\
\hline mst & million short tons \\
\hline Mt & million metric tons \\
\hline NOGA & National Oil and Gas Assessment; see glossary \\
\hline ppm & parts per million \\
\hline psi & pounds per square inch \\
\hline $\mathrm{R}_{\mathrm{PV}}$ & residual trapping pore volume; see glossary \\
\hline $\mathrm{R}_{\mathrm{SE}}$ & residual trapping storage efficiency; see glossary \\
\hline $\mathrm{R}_{\mathrm{SR}}$ & residual trapping storage resource; see glossary \\
\hline $\mathrm{R}_{\mathrm{SV}}$ & residual trapping storage volume; see glossary \\
\hline $\mathrm{R} 1 \mathrm{pV}$ & residual trapping class 1 pore volume \\
\hline $\mathrm{R} 1 \mathrm{SE}$ & residual trapping class 1 storage efficiency \\
\hline $\mathrm{R} 1_{S R}$ & residual trapping class 1 storage resource \\
\hline R1sv & residual trapping class 1 storage volume \\
\hline $\mathrm{R} 2 \mathrm{PV}$ & residual trapping class 2 pore volume \\
\hline $\mathrm{R} 2_{\mathrm{SE}}$ & residual trapping class 2 storage efficiency \\
\hline $\mathrm{R} 2 \mathrm{SR}$ & residual trapping class 2 storage resource \\
\hline
\end{tabular}




$\begin{array}{ll}\text { R2 } & \text { residual trapping class } 2 \text { storage volume } \\ \text { R3PV } & \text { residual trapping class 3 pore volume } \\ \text { R3SE } & \text { residual trapping class } 3 \text { storage efficiency } \\ \text { R3SR } & \text { residual trapping class } 3 \text { storage resource } \\ \text { R3sv } & \text { residual trapping class } 3 \text { storage volume } \\ \text { SAU } & \text { storage assessment unit; see glossary } \\ \text { SAUs } & \text { storage assessment units } \\ \text { SF } & \text { storage formation; see glossary } \\ \text { SFPV } & \text { storage formation pore volume; see glossary } \\ \text { TASR } & \text { technically accessible storage resource; see glossary } \\ \text { TAsV } & \text { technically accessible storage volume; see glossary } \\ \text { TDS } & \text { total dissolved solids; see glossary } \\ T_{P I} & \text { thickness of the porous interval; see glossary } \\ \text { USGS } & \text { U.S. Geological Survey } \\ \rho C O_{2} & \text { density of carbon dioxide } \\ \phi & \text { porosity; see glossary } \\ \phi P I & \text { porosity of the porous interval }\end{array}$




\title{
A Probabilistic Assessment Methodology for Evaluation of Geologic Carbon Dioxide Storage
}

\author{
By Sean T. Brennan, Robert C. Burruss, Matthew D. Merrill, Philip A. Freeman, and Leslie F. Ruppert
}

\section{Introduction}

\subsection{Purpose and Scope}

In 2007, the Energy Independence and Security Act (Public Law 110-140) authorized the U.S. Geological Survey (USGS) to conduct a national assessment of potential geologic storage resources for carbon dioxide $\left(\mathrm{CO}_{2}\right)$ in cooperation with the U.S. Environmental Protection Agency (EPA) and the U.S. Department of Energy (DOE). The first year of that activity was specified for development of a methodology to estimate storage potential that could be applied uniformly to geologic formations across the United States. After its release, the methodology was to receive public comment and external expert review. An initial methodology was developed and published in March 2009 (Burruss and others, 2009), and public comments were received. The report was then sent to a panel of experts for external review. The external review report was received by the USGS in December 2009.

This report is in response to those external comments and reviews and describes how the previous assessment methodology (Burruss and others, 2009) was revised. The resource that is assessed is the technically accessible storage resource, which is defined as the mass of $\mathrm{CO}_{2}$ that can be stored in the pore volume of a storage formation. The methodology that is presented in this report is intended to be used for assessments at scales ranging from regional to subbasinal in which storage assessment units are defined on the basis of common geologic and hydrologic characteristics. The methodology does not apply to site-specific evaluation of storage resources or capacity (see section 1.2). Calculations of subsurface pore volume for potential $\mathrm{CO}_{2}$ storage have been described in a number of publications (Bachu, 2003; Bradshaw, 2004; Bachu and others, 2007; U.S. Department of Energy, National Energy Technology Laboratory, 2008; van der Meer and Egberts, 2008). The methodology in this report is different in that it uses fully probabilistic methods to incorporate geologic uncertainty in calculations of storage potential.

Oil and gas assessments conducted by the USGS evaluate the resource that is estimated to be technically recoverable using current and projected technologies. These assessments are fractions of the total in-place resource that may be recoverable with technological advances or unforeseen changes in economic factors. Similarly, this assessment methodology for $\mathrm{CO}_{2}$ storage resources focuses on the technically accessible resource, not a total in-place resource volume. The technically accessible storage resource is one that may be available using present-day geological and engineering knowledge and technology for $\mathrm{CO}_{2}$ injection into geologic formations. The methodology is not an economic assessment, nor does it incorporate engineering constraints in the estimation of the volume of the resource. However, the methodology does take into account the U.S. Environmental Protection Agency (2008) proposed limit of 10,000 ppm (parts per million; mg/L (milligrams per liter)) total dissolved 
solids (TDS) for injection of $\mathrm{CO}_{2}$ into storage formations. Potential storage formations with salinities less than 10,000 ppm (mg/L) TDS will not be assessed using this methodology.

The methodology described in this report is for estimating the storage resource of an individual storage assessment unit, and it is designed as a guide for geologists to follow in the USGS national geologic $\mathrm{CO}_{2}$ storage assessment. During the course of the assessment we will develop additional methods to combine, or aggregate, resources of multiple storage assessment units within a basin and multiple regions and develop statistical algorithms that can address dependencies. The reporting of aggregated resource values ensures that policymakers and the public have access to information about $\mathrm{CO}_{2}$ storage resources for the Nation at a variety of scales.

\subsection{The Legislation}

Section 711 of the Energy Independence and Security Act (Public Law 110-140) (hereafter referred to as "EISA") specifies these requirements for the methodology:

\section{SEC. 711. CARBON DIOXIDE SEQUESTRATION CAPACITY ASSESSMENT.}

(a) DEFINITIONS. - In this section-

(1) ASSESSMENT.- The term " assessment" means the national assessment of onshore capacity for carbon dioxide completed under subsection (f).

(2) CAPACITY.-The term "capacity" means the portion of a sequestration formation that can retain carbon dioxide in accordance with the requirements (including physical, geological, and economic requirements) established under the methodology developed under subsection (b).

(3) ENGINEERED HAZARD.-The term "engineered hazard" includes the location and completion history of any well that could affect potential sequestration.

(4) RISK.- The term "risk' includes any risk posed by geomechanical, geochemical, hydrogeological, structural, and engineered hazards.

(5) SECRETARY.- The term "Secretary'" means the Secretary of the Interior, acting through the Director of the United States Geological Survey.

(6) SEQUESTRATION FORMATION.-The term "sequestration formation" means a deep saline formation, unmineable coal seam, or oil or gas reservoir that is capable of accommodating a volume of industrial carbon dioxide.

(b) METHODOLOGY.- Not later than 1 year after the date of enactment of this Act, the Secretary shall develop a methodology for conducting an assessment under subsection (f), taking into consideration-

(1) the geographical extent of all potential sequestration formations in all States;

(2) the capacity of the potential sequestration formations;

(3) the injectivity of the potential sequestration formations;

(4) an estimate of potential volumes of oil and gas recoverable by injection and sequestration of industrial carbon dioxide in potential sequestration formations;

(5) the risk associated with the potential sequestration formations; and

(6) the work done to develop the Carbon Sequestration Atlas of the United States and Canada that was completed by the Department. 
A complete version of the EISA can be found at http://frwebgate.access.gpo.gov/cgibin/getdoc.cgi?dbname=110_cong_public_laws\&docid=f:publ140.110.pdf.

The EISA requires the USGS to assess the capacity of the sequestration formations; however, this term has become synonymous with "reserves" in the $\mathrm{CO}_{2}$ community (Burruss, 2009; Frailey and Finley, 2009; Gorecki and others, 2009). The USGS assesses resources, which are considered to be independent of economic constraints. Reserves are the fraction of the resource that has economic value (Juanes and others, 2010). The definition of "capacity" as specified in the EISA is equivalent to the term "resource"; therefore, this methodology describes a method to assess the storage resource, which is the mass of the free-phase $\mathrm{CO}_{2}$ that can be retained within a sequestration formation. Solubility trapping and mineral trapping of $\mathrm{CO}_{2}$ (Benson and Cook, 2005; Bradshaw and others, 2007) are not included in this methodology.

The legislative definition of "risk" contains two distinct classes of risk factors: geologic and engineering. The first, as stated in section 711(a)(4) of the EISA, includes "geomechanical, geochemical, hydrogeological, [and] structural ... hazards." These are naturally occurring, geologically based parameters, which are accounted for in the methodology through the input distributions for geologic parameters and storage efficiency that are described in section 3 of this report. In addition, we assume that sound engineering practices will be employed on a site-specific scale to minimize structural and environmental hazards. This assumption is necessary, because the quantification of risk is more appropriately a site-specific process that requires time and resources to yield meaningful results. These resources are not available for the investigation of the storage formations in this national assessment. Wiprut and Zoback (2000) and Lucier and Zoback (2008) provide examples of the potential interaction between $\mathrm{CO}_{2}$ injection and faults as an example of this research. The second risk is "engineered hazards," which are primarily a result of the impact of drilling procedures, drilling history, and drilling density. Such hazards are potential engineering constraints that are not considered in this methodology's evaluation of the probability of $\mathrm{CO}_{2}$ retention in the storage formation. However, illustrations of drilling density will be generated as part of the assessment process to provide information about the potential scale of engineered hazards.

A sequestration formation, as defined in section 711(a)(6) of EISA, is "a deep saline formation, unmineable coal seam, or oil and gas reservoir that is capable of accommodating a volume of industrial carbon dioxide." These three geologic environments may occur within the same geologic interval and may share common geologic characteristics that affect the size of the potential storage resource. This report only addresses the potential storage resource of two of these environments: deep saline formations and oil and gas reservoirs. Because there is no standard definition of "unmineable coal seams," the potential storage resource of this environment will not be addressed in this report. The DOE, however, has published estimates for $\mathrm{CO}_{2}$ storage capacity in coal seams (U.S. Department of Energy, National Energy Technology Laboratory, 2008). When a commonly accepted definition of unmineable coal is determined, the USGS will incorporate the potential storage resource of this environment in future $\mathrm{CO}_{2}$ storage assessment reports.

As described in detail in the following sections of this report, we will use the term "storage formation" (SF) for sequestration formation. The SF together with enclosing seal formations constitute a storage assessment unit (SAU) that is the fundamental geologic unit to be assessed for $\mathrm{CO}_{2}$ storage resources.

Section 711(b)(3) of the EISA also specifies that the methodology consider "the injectivity of the potential sequestration formations." Quantification of injectivity, as defined in the hydrologic and petroleum reservoir literature, requires measurement of pressure changes in a well resulting from injection of a known volume of fluid for a known period of time (Craft and Hawkins, 1991). Although 
large volumes of fluid are injected into the subsurface during oil field and waste disposal operations, data from such operations, as reported by State and Federal agencies, are limited. This lack of adequate injection and associated pressure data from geologic formations across the country makes the development of performance-based, numerical "injectivity" criteria for an assessment methodology difficult. As a proxy, this assessment uses permeability categories in addition to lithologic information to more appropriately select the storage efficiencies used to calculate the storage resource values.

Section 711(b)(4) of the EISA directs the USGS to provide "an estimate of potential volumes of oil and gas recoverable by injection and sequestration of industrial carbon dioxide in potential sequestration formations." Methodologies for calculating enhanced oil recovery and enhanced gas recovery estimates are not included in this report. However, estimates of the volume of petroleum that can be recovered by $\mathrm{CO}_{2}$ sequestration to meet this requirement of the EISA will be discussed at a later time in a separate document.

\section{Assessment Framework}

\subsection{Assessment Methodologies}

Storage resources for geologic sequestration of $\mathrm{CO}_{2}$ have been estimated using many methodologies for a variety of scales, ranging from global to single basins. A review of many of these estimates (Bradshaw and others, 2005) concluded that assessments of similar areas varied by as much as a factor of 100 or more. In an attempt to provide consistent methods that are based on clearly defined input parameters, a working group of the "Carbon Sequestration Leadership Forum" created deterministic methods (Bradshaw and others, 2007; Bachu and others, 2007) that could be applied anywhere in the world. A group of researchers led by Scott Frailey at the Illinois State Geological Survey developed the methodologies for $\mathrm{CO}_{2}$ storage capacity that were used in the DOE Regional Carbon Sequestration Partnership program "National Carbon Atlas" (U.S. Department of Energy, National Energy Technology Laboratory, 2008, their appendix B.) Another important assessment method, formulated by van der Meer and Egberts (2008), incorporates the impact of the pressure front created by the injection of $\mathrm{CO}_{2}$. This pressure front propagates away from the injection site in advance of the plume of injected $\mathrm{CO}_{2}$, thereby affecting a much larger area of a storage formation. The methods described above are not fully probabilistic. However, probabilistic methods have been used to calculate storage efficiency values (see definition and discussion below) but do not account for the full range of geologic uncertainty in the resource calculation (U.S. Department of Energy, National Energy Technology Laboratory, 2008; Gorecki and others, 2009).

Over a number of years, the USGS has developed probabilistic methods for assessing energy resources (Charpentier and Klett, 2005; Schmoker and Klett, 2005) that can be applied to environments ranging from mature exploration provinces to relatively unexplored areas such as those found in the circum-Arctic (Bird and others, 2008; Gautier and others, 2009). Assessments of natural resources can be performed in many ways, and each method has advantages and disadvantages that are related to different input parameters, resource models, treatment of geologic uncertainty, and propagation of uncertainty to the results. Ahlbrandt and Klett (2005) reviewed and quantitatively compared seven methods of oil and gas resource assessment with the USGS methods used in the 2000 World Energy Project. They concluded that the probabilistic methods used by the USGS are robust and reproducible. Probabilistic methods are needed for assessments because geologic data for large areas are rarely complete. Because rocks are heterogeneous, approximations are required to fill gaps in the data. Probabilistic methods provide a statistically sound method to make these approximations. However, as emphasized by Charpentier and Klett (2005) and demonstrated by Ahlbrandt and Klett (2005), a critical 
component of probabilistic resource assessment is careful integration of the geologic model of the resource with the statistical analyses of the probabilistic methods.

\subsection{Model for $\mathrm{CO}_{2}$ Storage Resources}

This methodology is designed to assess the storage resources in mappable subsurface bodies of rock into which $\mathrm{CO}_{2}$ is injected and trapped; in this methodology, these mappable subsurface bodies of rock are referred to as storage assessment units (SAUs). The total volume of pore space within a SAU can be described as the total in-place resource. This report addresses the fraction of that total resource that may retain $\mathrm{CO}_{2}$. The mass retained in that fraction is the technically accessible storage resource $\left(\mathrm{TA}_{\mathrm{SR}}\right)$. The technically accessible storage resource is defined as the mass of $\mathrm{CO}_{2}$ that can be stored in the pore volume of the SF taking into account present-day geologic knowledge and engineering practice and experience. The $\mathrm{TA}_{\mathrm{SR}}$ is analogous to the term "technically recoverable resource" used in USGS oil and gas assessments.

Carbon dioxide is injected into the subsurface as a separate fluid phase that is less dense than formation water, migrates by buoyancy, and is retained in the subsurface by capillary forces. $\mathrm{CO}_{2}$ will rise buoyantly until it encounters a rock unit that has a capillary entrance pressure that is greater than the buoyancy or hydrodynamic forces. Additional $\mathrm{CO}_{2}$ will accumulate until the buoyancy force exceeds the capillary entrance pressure of the pore space vertically or laterally adjacent to the $\mathrm{CO}_{2}$ plume. If the overlying rock unit has sufficiently high capillary entrance pressure, it will act as a seal, allowing $\mathrm{CO}_{2}$ to accumulate in any structural or stratigraphic feature that has both vertical and lateral seals. In the geologic model for this assessment methodology, the pore space within large geologic structures that will retain $\mathrm{CO}_{2}$ in this manner is called the buoyant trapping storage resource $\left(\mathrm{B}_{\mathrm{SR}}\right)$. In basins that have produced oil and gas, many of these structures involve petroleum reservoirs. Buoyant trapping storage resource estimates are based on data from petroleum reservoirs that have more than 500,000 barrels of oil equivalent (BOE) and, if available, information from other similar-size enclosures (for example, dry traps).

A mass of $\mathrm{CO}_{2}$ injected into a volume of rock will form a plume that migrates buoyantly and will continue to migrate after injection stops. The capillary entrance pressures of the pore spaces within the SF are heterogeneous. These heterogeneities within the SF may impede the flow of the migrating plume of $\mathrm{CO}_{2}$, causing some of the $\mathrm{CO}_{2}$ to be retained within the pore spaces. These heterogeneities range in size - as small as individual pores (Juanes and others, 2006) through meter-size features like clay drapes within crossbedded sandstones (Saadatpoor and others, 2010) to petroleum reservoir-size enclosures, which house the buoyant pore volume. The key concept is that the plume must migrate and leave behind some fraction of the $\mathrm{CO}_{2}$ trapped in these heterogeneities. The plume will continue to migrate until the mass of $\mathrm{CO}_{2}$ within the plume is so small that the buoyancy forces within the plume are less than the capillary injection pressures of the formation. In other words, these volumes of trapped $\mathrm{CO}_{2}$ from the migration of the $\mathrm{CO}_{2}$ plume are the residues of the migration process. The fraction of the pore space that physically traps $\mathrm{CO}_{2}$ in volumes less than petroleum reservoir-size enclosures is most typically referred to as residual $\mathrm{CO}_{2}$ trapping (Benson and Cook, 2005; Bradshaw and others, 2007; Gorecki and others, 2009), although Saadatpoor and others (2010) subdivide the pore-size and metersize retention mechanisms into residual and capillary trapping, respectively. In this methodology, all potential $\mathrm{CO}_{2}$ trapping within the $\mathrm{SF}$ that is smaller than the petroleum reservoir-size enclosures is defined as the residual trapping storage resource $\left(\mathrm{R}_{\mathrm{SR}}\right)$.

The amount and quality of information available to estimate the mass of $\mathrm{CO}_{2}$ that could be stored vary. In geologic provinces that have oil and gas production, detailed information is available on some or most of the structural and stratigraphic features that are part of the buoyant trapping storage 
resource. However, such features are but a small fraction of the storage formation. The rest of the storage formation is a candidate for residual storage. The residual trapping storage resource is potentially much larger than the buoyant trapping storage resource, but within petroleum reservoir-size enclosures, the trapping processes and the relative fraction of pore space in which residual storage resources may occur are not as well understood as buoyant storage resources. The relative size of the two resources and the relative certainty with which we may be able to estimate the resources are illustrated in figure 1. The top part of the triangle represents the resource that is most understood but has the smaller resource; the bottom part of the triangle represents the resource that is least understood but has the larger resource. In provinces with no oil and gas production, most of the resource could be residual storage.
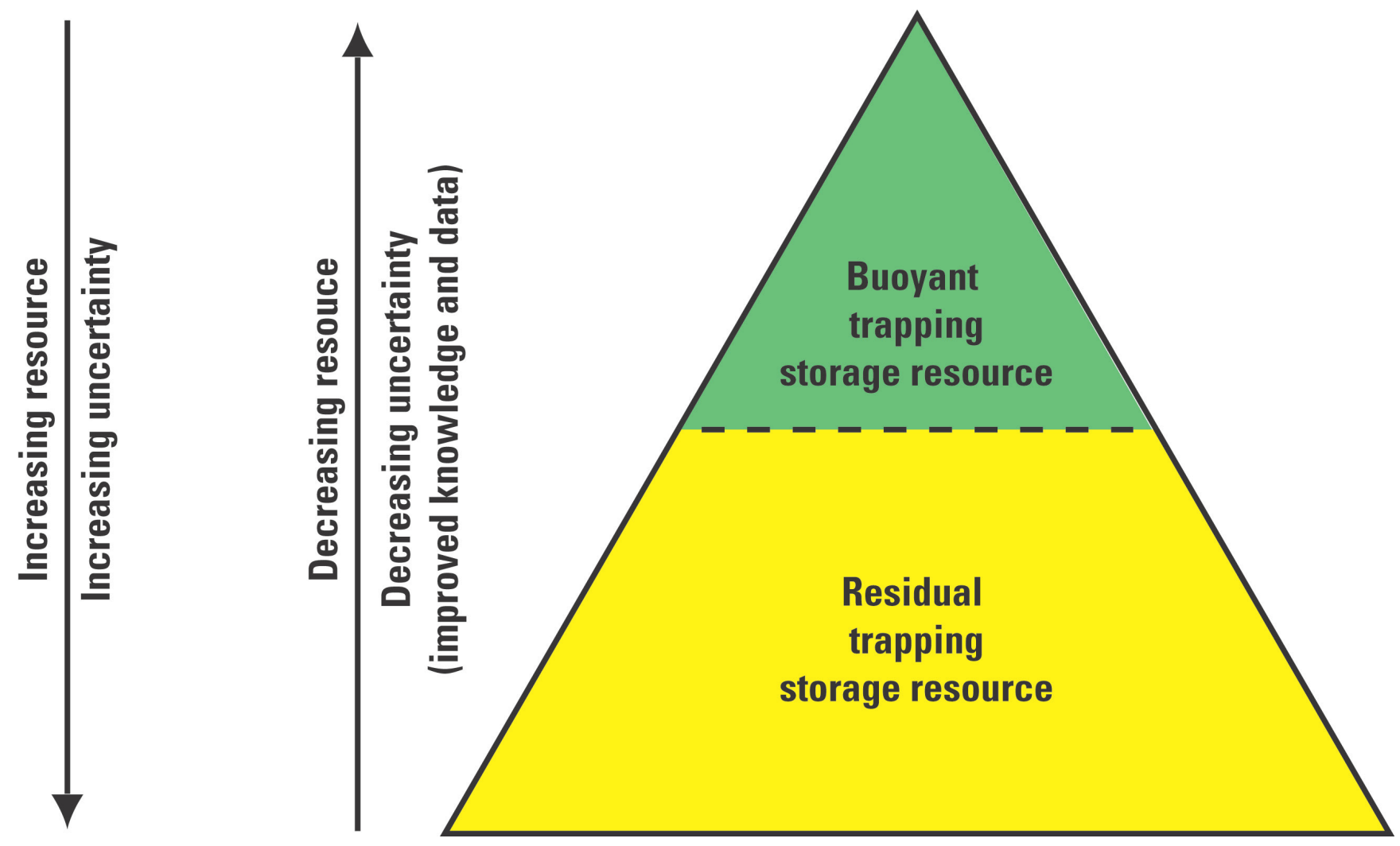

Figure 1. A resource triangle depicting the relation between buoyant and residual trapping storage resources that schematically illustrates the relation between uncertainties in knowledge of the resource and the relative volume of the resource.

This general discussion of buoyant and residual trapping does not supplant the rich and diverse datasets and geologic models for petroleum entrapment that are based on 100 years of exploration and production. There is no comparable dataset for $\mathrm{CO}_{2}$ sequestration; only a few field trials have been undertaken thus far. As a consequence, the mechanics of assessing $\mathrm{CO}_{2}$ storage resources incorporates parameters that are poorly known due to limited data from $\mathrm{CO}_{2}$ injection projects. Adopting a probabilistic method does not serve as a cure for lack of knowledge, but merely quantifies the higher level of uncertainty that is necessarily inherent in $\mathrm{CO}_{2}$ storage resource assessments. 


\subsection{Geologic Framework}

\subsubsection{Storage Assessment Unit-Storage Formation}

The storage assessment unit (SAU) is a mappable volume of rock that consists of a porous flow storage unit and a bounding regional sealing formation. Within the SAU, the porous flow unit is defined as the storage formation (SF). A schematic cross section that extends downdip through a hypothetical SAU is shown in figure 2 . The pore volume within the SF that contains the buoyant trapping storage resources and the residual trapping storage resources are shown in color.

Schematic Storage Formation Model

Storage Assessment Unit, Cross Section

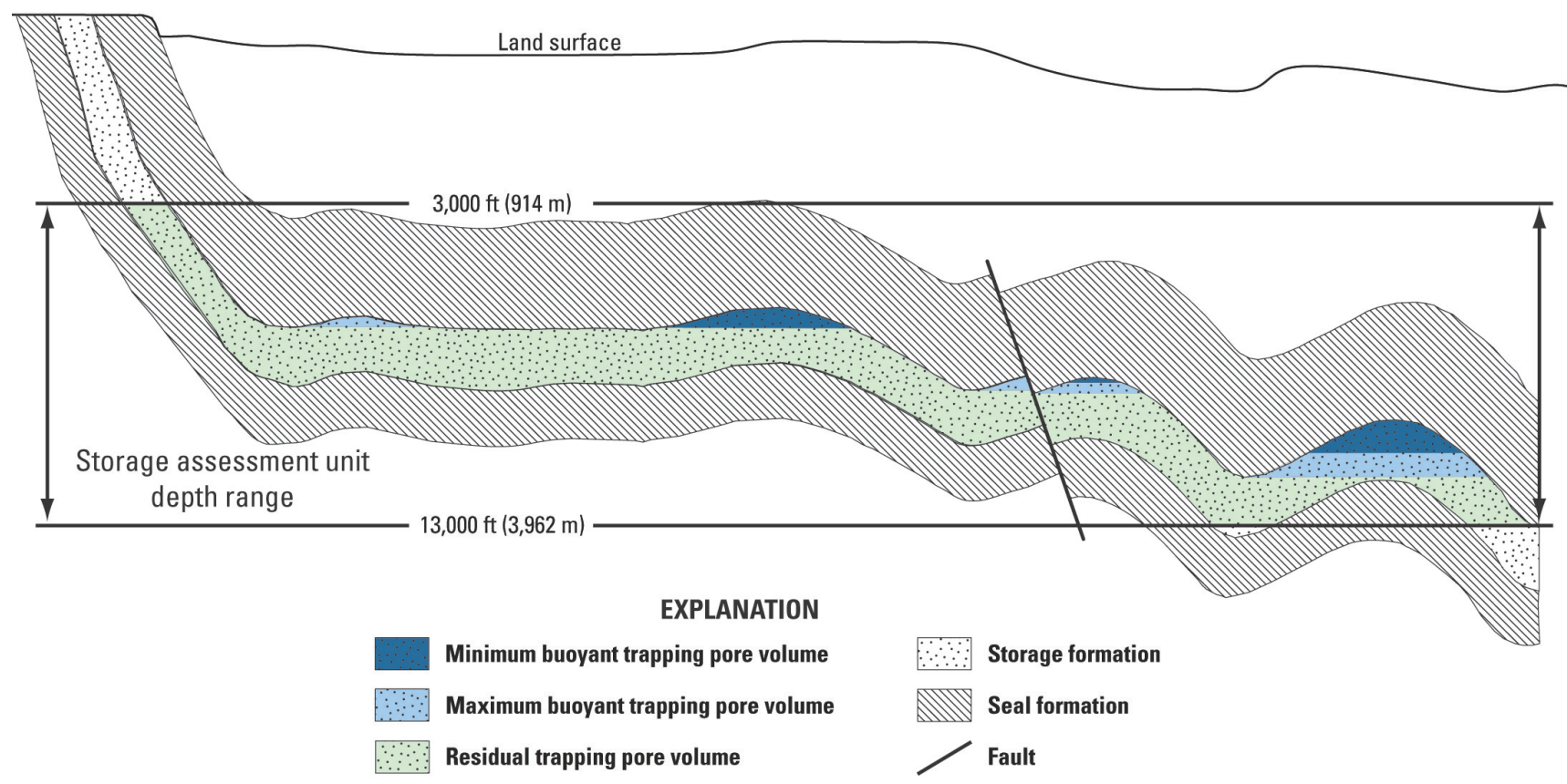

Figure 2. A schematic cross section through a storage assessment unit (SAU) illustrating the relation between buoyant and residual trapping styles in the storage formation. Recommended SAU depth limits of $3,000 \mathrm{ft}(914 \mathrm{~m})$ and $13,000 \mathrm{ft}(3,962 \mathrm{~m})$ also are included.

The extent of the SF is defined by the physical properties of $\mathrm{CO}_{2}$. The upper vertical limit chosen for this methodology is 3,000 feet $\left(914 \mathrm{~m}\right.$ ) (Burruss and others, 2009) because $\mathrm{CO}_{2}$ at this depth is typically subjected to temperatures and pressures that maintain the $\mathrm{CO}_{2}$ in a supercritical state. Supercritical $\mathrm{CO}_{2}$ has density values much higher than those of gaseous $\mathrm{CO}_{2}($ National Institute of Standards, 2009). The lower vertical limit for the SAU of 13,000 feet $(3,962 \mathrm{~m})$ is based on the potential $\mathrm{CO}_{2}$ injection depth at pipeline pressures without additional compression at the surface. The justification for these limits is discussed in more detail in Burruss and others (2009). If rock properties suggest that a viable storage resource is present at depths below 13,000 ft, the assessment geologist may 
add an additional SAU for this deeper reservoir. The areal extent of the SAU on a map is defined by depth contours, from the land surface to the top of the SF, at 3,000 and 13,000 feet (914 and 3,962 m).

Additional factors may limit the areal extent of the SF. For example, any formation water with salinities lower than 10,000 ppm (mg/L) TDS, regardless of depth, has the potential to be used as a potable water supply (U.S. Environmental Protection Agency, 2009). The U.S. Environmental Protection Agency (2008) has proposed the 10,000 ppm (mg/L) TDS limit for injection of $\mathrm{CO}_{2}$. Therefore, the potential storage resources for $\mathrm{CO}_{2}$ in formations with salinities less than 10,000 ppm (mg/L) TDS will not be assessed at this time, except to illustrate the methodology in section 4. Although salinities of formation water commonly increase with depth, formation water within an assessment unit may be less saline than the $10,000 \mathrm{ppm}(\mathrm{mg} / \mathrm{L})$ limit near the updip extent of the SF, eliminating a part of the SAU.

\subsubsection{Storage Assessment Unit-Seal Formation}

Seal formations (confining units, aquitards, cap rock) are regional geologic strata that inhibit the migration of fluids between adjacent geologic strata. The seal formation must be present for identification of the mappable extent of the SAU. Therefore, any area of the SF that is not beneath the seal formation is excluded from the area of the SAU. A seal may consist of single or multiple formations.

Seals need to be evaluated for the leakage potential of $\mathrm{CO}_{2}$ and formation water from the SF. The two primary pathways of fluids through a seal that may account for seal failure are (1) leakage through fractures and faults and (2) diffuse porous flow where the capillary entrance pressure of the seal is exceeded by the pore pressure as determined by the column height of the fluids (Hermanrud and others, 2005). Diffuse porous flow is not considered to be a significant factor in the movement of fluids through seals (Couples, 2005). However, studies of seal fractures in oil and gas fields indicate that fracture flow can account for large volumes of fluid movement through the seal (Skerlec, 1999). The integrity of the fault seal may be affected by the juxtaposition of the strata within the fault plane, fluid pressures, mineralogy, and geometry of the fault system.

\section{Storage Resource Calculations}

This methodology estimates the technically accessible storage resource (TA $\left.\mathrm{TR}_{\mathrm{SR}}\right)$, which is the mass of $\mathrm{CO}_{2}$ that can be stored in the pore volume of the SF. This resource is the product of $\mathrm{CO}_{2}$ density and storage volume, which is the fraction of the pore volume that will retain injected $\mathrm{CO}_{2}$. In order to estimate this fractional volume, the storage formation pore volume $\left(\mathrm{SF}_{\mathrm{PV}}\right)$ is calculated and then allocated between the pore volume available for buoyantly trapped $\mathrm{CO}_{2}$ and residually trapped $\mathrm{CO}_{2}$ ( $\mathrm{B}_{\mathrm{PV}}$ and $\mathrm{R}_{\mathrm{PV}}$, respectively). The $\mathrm{B}_{\mathrm{PV}}$ and $\mathrm{R}_{\mathrm{PV}}$ are calculated separately because they are modified by different geologic uncertainties and storage efficiencies. Storage efficiency is the value that represents the fraction of the total available pore space that will retain free-phase $\mathrm{CO}_{2}$. The following sections $\left(3.1,3.2\right.$, and 3.3) describe $\mathrm{SF}_{\mathrm{PV}}, \mathrm{B}_{\mathrm{PV}}$, and $\mathrm{R}_{\mathrm{PV}}$ and how they are derived and used to generate probabilistic assessment storage resource estimates (fig. 3) using a Monte Carlo simulator. The assessment geologist is tasked with determining the input parameters using the information available. These input parameters are recorded on the input data form shown in appendix A. To facilitate the process, data, when available, will be provided to the geologist by the $\mathrm{CO}_{2}$ assessment team, a core group of USGS scientists working in support of the $\mathrm{CO}_{2}$ storage assessment activities. 


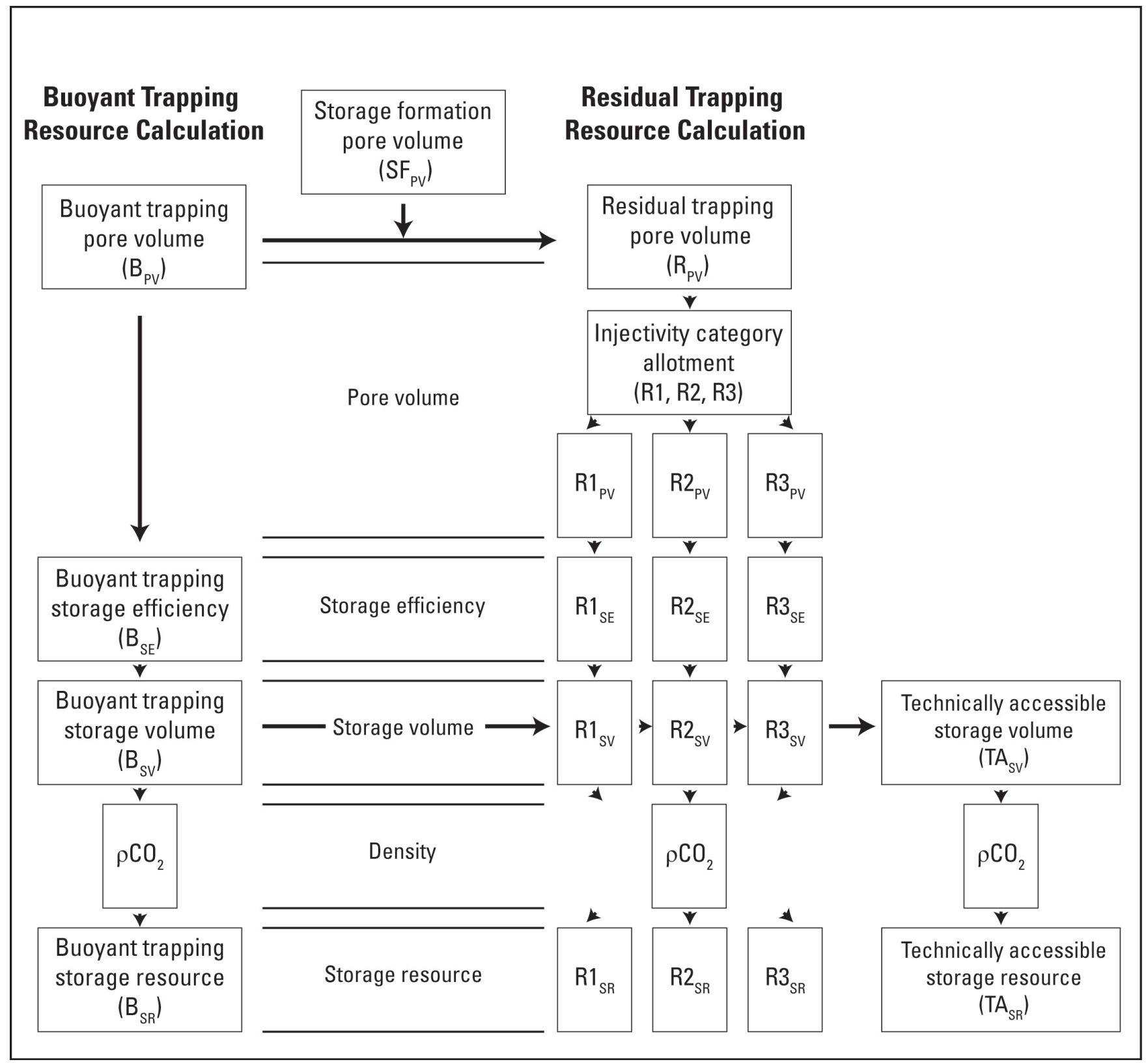

Figure 3. Flow diagram of key steps for calculating buoyant trapping storage resources (left) and residual trapping storage resources (right). Injectivity categories are represented as class 1 (R1), class 2 (R2), and class 3 (R3). See text for more information.

\subsection{Calculating Storage Formation Pore Volume}

The first step of the assessment process is to define the area of the SAU. Using available databases, the $\mathrm{CO}_{2}$ assessment team provides the assessment geologist with values for the area, net porous thickness, and porosity. The area of the SAU is determined via GIS techniques (appendix B) by the assessment team on the basis of the maps of the SF created using the parameters discussed in section 2.3.1. The values for net porous thickness and porosity can be further refined if relevant data are gathered by the assessment geologist during research for the framework geology of the SAU. Because 
the area of the SF is typically clearly defined, the uncertainty for mean area of the SF is likely to be relatively small. However, thickness and porosity data that are either localized, such as data primarily from oil and gas fields, or sparse to nonexistent, such as data from a formation with few well penetrations, could lead to significant uncertainty about whether the mean values calculated from those data accurately represent the entire SF. These input values will be determined by the assessment geologist in consultation with the assessment team. The probabilistic product of mean SAU area, mean thickness of the net porous interval, and mean porosity is the storage formation porous volume as shown in equation 1.

$$
S F_{P V}=A_{S F} \times T_{P I} \times \phi_{P I}
$$

where $\mathrm{SF}_{\mathrm{PV}}$

$\mathrm{A}_{\mathrm{SF}}$

$\mathrm{T}_{\mathrm{PI}}$

is the pore volume of the storage formation (fraction);

is the mean area of the storage formation (acres);

is the mean thickness of the porous interval (feet), where the porous interval is

defined as the stratigraphic thickness of the storage formation with a porosity

of 8 percent or higher; and

$\phi_{\mathrm{PI}}$

is the mean porosity of the porous interval (fraction).

\subsection{Calculating Buoyant Trapping Pore Volume}

The buoyant trapping pore volume $\left(\mathrm{B}_{\mathrm{PV}}\right)$ is a geologically determined, probabilistic distribution of the volume of the SF that can store $\mathrm{CO}_{2}$ by buoyant trapping. The assessment geologist is tasked to generate the $\mathrm{B}_{\mathrm{PV}}$ distribution by using all available information. However, defaults may be used for the input data that define the $\mathrm{B}_{\mathrm{PV}}$ distribution.

The minimum $\mathrm{B}_{\mathrm{PV}}$ input can be the volume of known recovery of petroleum, scaled to subsurface volumes. The $\mathrm{CO}_{2}$ assessment team will sum the known recovery production volumes (KR) of oil and gas reservoirs within the SAU from available databases and use formation volume factors (FVFs) to convert these surface volumes to volumes at reservoir conditions (KR $\mathrm{KES})$. The KR for oil and natural gas liquids will be corrected to subsurface volumes by using an appropriate range of FVFs for the SAU from the Standing correlation (Beggs, 1987). The KR for gas will be corrected to subsurface volumes using appropriate compressibility factors for the range of temperatures and pressures (Garb and Smith, 1987) within the SAU.

$$
K R_{R E S}=\left[\left(\left(K R_{O I L}+K R_{N G L}\right) \times F V F_{O I L}\right)+\left(K R_{G A S} \times F V F_{G A S}\right)\right]
$$

where $\mathrm{KR}_{\mathrm{RES}}$

$\mathrm{KR}_{\mathrm{OIL}}$

is the volume of known recovery corrected to reservoir conditions (volume);

$\mathrm{KR}_{\mathrm{NGL}}$

is the known recovery of oil (volume);

$\mathrm{FVF}_{\mathrm{OIL}}$ is the known recovery of natural gas liquids (volume);

$\mathrm{KR}_{\mathrm{GAS}}$ is the formation volume factor for oil and natural gas liquids (fraction);

$\mathrm{FVF}_{\mathrm{GAS}}$ is the known recovery of gas (volume); and is the formation volume factor for gas (fraction).

An additional estimation of buoyant trapping that can be used in this methodology is the reported mean values for USGS National Oil and Gas Assessment (NOGA) undiscovered petroleum resource volumes. NOGA mean resource volumes can be allocated to the SF; these allocated volumes are then corrected to reservoir conditions using equation (2). The corrected undiscovered NOGA volumes can be added to the $\mathrm{KR}_{\mathrm{RES}}$ value to estimate a more robust buoyant trapping volume. If there are any buoyant traps without petroleum production ("dry traps" within the SF), then it may be possible 
to incorporate their volumes into the KRRES and USGS NOGA undiscovered petroleum resource estimates to determine a median BPV. However, because there are no known available datasets on "dry trap" characteristics, estimating any volume comparable to USGS NOGA or KR RES values will be difficult. The maximum $\mathrm{B}_{\mathrm{PV}}$ input should likely include some estimate of the volume of the total pore space that is within large enclosures. However, the assessment geologist can estimate the $\mathrm{B}_{\mathrm{PV}}$ distribution in any way using the data provided in conjunction with all other available geologic data.

The $\mathrm{B}_{\mathrm{PV}}$ is multiplied by the buoyant trapping storage efficiency $\left(\mathrm{B}_{\mathrm{SE}}\right.$, fig. 3 ) to determine a buoyant trapping storage volume $\left(\mathrm{B}_{\mathrm{SV}}\right)$, as shown in equation 3 . Typically, $\mathrm{B}_{\mathrm{SE}}$ is lower than hydrocarbon saturation values in oil or gas fields. This difference is due to the inability of a low viscosity fluid, such as supercritical $\mathrm{CO}_{2}$, to efficiently displace a high viscosity fluid, such as oil or water, without exceeding the fracture pressure of the storage or seal formation. Also, because there are no $\mathrm{CO}_{2}$ storage projects that have attempted to optimize the mass of $\mathrm{CO}_{2}$ that can be retained within the pore volume of an enclosure, buoyant trapping storage efficiencies are difficult to estimate. The buoyant trapping storage efficiencies $\left(\mathrm{B}_{\mathrm{SE}}\right)$ used in this study will be based on experimentally derived relative permeability curves (Bennion and Bachu, 2005, 2008; Burton and others, 2008). Values from such studies provide the best potential storage efficiencies that are currently available for buoyant storage, but these values could change with more research or field data.

$$
B_{S V}=B_{P V} \times B_{S E}
$$

where $\mathrm{B}_{\mathrm{SV}}$

$$
\begin{array}{ll}
\mathrm{B}_{\mathrm{PV}} & \text { is the pore volume available for buoyant trapping (volume); and } \\
\mathrm{B}_{\mathrm{SE}} & \text { is the storage efficiency of buoyant } \mathrm{CO}_{2} \text { storage (fraction). }
\end{array}
$$

To determine the buoyant trapping storage resource $\left(\mathrm{B}_{\mathrm{SR}}\right)$, which is the mass of $\mathrm{CO}_{2}$ that can be buoyantly trapped in the $\mathrm{SF}$, the $\mathrm{B}_{\mathrm{SV}}$ is multiplied by the density of $\mathrm{CO}_{2}$ (as shown in equation 4 and illustrated in figure 3). A probabilistic distribution of the density of $\mathrm{CO}_{2}$ is calculated by the assessment team based on the upper and lower depth boundaries of the SF, temperature and pressure gradients appropriate for the area, and an equation of state for $\mathrm{CO}_{2}$.

$$
B_{S R}=B_{S V} \times \rho \mathrm{CO}_{2}
$$

where $\mathrm{B}_{\mathrm{SR}} \quad$ is the buoyant trapping storage resource (mass);

$\mathrm{B}_{\mathrm{SV}} \quad$ is the volume of $\mathrm{CO}_{2}$ stored by buoyant trapping with the storage formation

(volume); and

$\mathrm{\rho CO}_{2} \quad$ is the density of $\mathrm{CO}_{2}$ (mass/volume).

With this step, the calculation for $\mathrm{B}_{\mathrm{SR}}$ is complete (fig. 3).

\subsection{Calculating Residual Trapping Pore Volume}

Residual trapping is the second type of storage in the storage formation resource calculation. The pore volume available for residual trapping is the remaining $\mathrm{SF}_{\mathrm{PV}}$ that was not considered for the buoyant storage resource. During the iterative calculations using the Monte Carlo simulator, a single value is selected from the $\mathrm{B}_{\mathrm{PV}}$ distribution; this value is subtracted from the $\mathrm{SF}_{\mathrm{PV}}$ selected in the same iteration and yields a remaining pore volume that is equal to the residual trapping pore volume $\left(\mathrm{R}_{\mathrm{PV}}\right)$ (fig. 3). 


$$
R_{P V}=S F_{P V}-B_{P V}
$$

This residual pore volume is apportioned into three rock classes or "injectivity category allotments" (fig. 3) on the basis of permeability. The $\mathrm{CO}_{2}$ assessment team will provide permeability values from available databases; however, the assessment geologist should seek to augment these values with data available from literature, other databases, or other sources. These permeability values are used to estimate the percentages of the SF that comprise each class. Storage efficiencies associated with residual trapping are poorly understood because commercial-scale injection projects into these parts of the SF have not been undertaken. Because these values are not well constrained, we will use a standard set of minimum, mode, and maximum values based on modeled values from Gorecki and others (2009) that have been modified by the injectivity and mobility of $\mathrm{CO}_{2}$.

Class 1 rocks are defined as those parts of the remaining SF that have very high permeabilities (greater than 1 Darcy) and the highest injectivity values. These highly permeable rocks, however, typically have less pore-scale residual trapping (Juanes and others, 2006), due to the lack of small pore throats. Therefore, the majority of the trapping in these rocks will be the result of larger scale permeability heterogeneities (Saadatpoor and others, 2010) as described in section 2. In addition, $\mathrm{CO}_{2}$ plumes would move quickly in a highly permeable unit, which would increase the potential for leakage along sections of the SF that crop out at the surface updip from the SAU boundary. The corresponding storage efficiency values for these rocks are typically lower than class 2 rocks due to the lack of porescale residual trapping of a highly mobile $\mathrm{CO}_{2}$ plume.

Class 2 rocks are defined as parts of the remaining SF that have (1) moderate permeabilities, typically on the order of 1 millidarcy to 1 Darcy; (2) minor to no injectivity issues as discussed in the guidelines of the U.S. Environmental Protection Agency (2008); and (3) a high potential for all types of residual trapping ranging from pore scale to larger scales. Class 2 rocks might have the highest storage efficiency values due to the full range of potential residual trapping types.

Class 3 rocks are defined as parts of the remaining SF that have low permeabilities, on the order of less than 1 millidarcy, and have little to no injectivity. These rocks have low storage efficiency values, with minimum and mode values approaching or equal to zero, since little $\mathrm{CO}_{2}$ will enter these rocks without artificially fracturing the rock; artificial fracturing of the SF may not be permitted under U.S. Environmental Protection Agency requirements (2008). The maximum value is taken from the appropriate sandstone, limestone, or dolomite values from Gorecki and others (2009) to account for the possibility that some mass of $\mathrm{CO}_{2}$ could enter and be retained within this part of the SF.

Using permeability data from the $\mathrm{SF}$, the $\mathrm{R}_{\mathrm{PV}}$ is then allocated between these three classes (R1, $\mathrm{R} 2$, and R3). During each iteration, the classes are then multiplied by a value from their fixed storage efficiency probability distributions to determine their residual volume resources $\left(\mathrm{R}_{\mathrm{SV}}\right)$ (fig. 3).

$$
R_{S V}=R_{P V} \times R_{S E}
$$

where $\mathrm{R}_{\mathrm{SV}} \quad$ is the residual trapping storage volume (volume);

$\mathrm{R}_{\mathrm{PV}} \quad$ is the residual trapping pore volume (volume); and

$\mathrm{R}_{\mathrm{SE}} \quad$ is the residual trapping storage efficiency (fraction).

The residual trapping storage resource $\left(\mathrm{R}_{\mathrm{SR}}\right)$ is determined by multiplying the $\mathrm{R}_{\mathrm{SV}}$ by the density of $\mathrm{CO}_{2}$ (fig. 3). A probabilistic distribution of the density of $\mathrm{CO}_{2}$ is calculated by the assessment team based on the upper and lower depth boundaries of the storage formation, temperature and pressure gradients appropriate for the area, and an equation of state for $\mathrm{CO}_{2}$. 


$$
R_{S R}=R_{S V} \times \rho \mathrm{CO}_{2}
$$

where $\mathrm{R}_{\mathrm{SR}} \quad$ is the residual trapping storage resource (mass); and

$\mathrm{\rho CO}_{2} \quad$ is the density of $\mathrm{CO}_{2}$ (mass/volume).

With this step, the calculation for $\mathrm{R}_{\mathrm{SR}}$ is complete (fig. 3 ).

\subsection{Technically Accessible Storage Resource}

In order to calculate the technically accessible storage resource (TA $\left.\mathrm{TA}_{\mathrm{SV}}\right)$ for the $\mathrm{SF}$ as a whole, the storage volumes calculated using the equations in sections 3.2 and 3.3 are summed iteratively (fig. 3).

$$
T A_{S V}=R 1_{S V}+R 2_{S V}+R 3_{S V}+B_{S V}
$$

where $\mathrm{TA}_{\mathrm{SV}} \quad$ is the technically accessible storage volume;

$\mathrm{R} 1_{\mathrm{SV}} \quad$ is the residual trapping class 1 storage volume;

$\mathrm{R} 2 \mathrm{SV} \quad$ is the residual trapping class 2 storage volume;

$\mathrm{R} 3_{\mathrm{SV}} \quad$ is the residual trapping class 3 storage volume; and

$\mathrm{B}_{\mathrm{SV}} \quad$ is the buoyant trapping storage volume.

The technically accessible storage resource $\left(\mathrm{TA}_{\mathrm{SR}}\right)$ is determined by multiplying the $\mathrm{TA}_{\mathrm{SV}}$ by the density of $\mathrm{CO}_{2}$ (fig. 3). A probabilistic distribution of the density of $\mathrm{CO}_{2}$ is calculated by the assessment team based on the upper and lower depth boundaries of the storage formation, temperature and pressure gradients appropriate for the area, and an equation of state for $\mathrm{CO}_{2}$.

$$
T A_{S R}=T A_{S V} \times \rho C O_{2}
$$

where $\mathrm{TA}_{\mathrm{SR}} \quad$ is the technically accessible storage resource (mass); and

$\mathrm{\rho CO}_{2} \quad$ is the density of $\mathrm{CO}_{2}$ (mass/volume).

With this step, the calculation for $\mathrm{TA}_{\mathrm{SR}}$ is complete (fig. 3).

\subsection{Storage in Oil and Gas Reservoirs}

The EISA legislation defines a sequestration formation as a "deep saline formation ... or oil or gas reservoir." Within SAUs that have petroleum production, the storage resource specific to petroleum reservoirs can be estimated by using the $\mathrm{KR}_{\mathrm{RES}}$ values determined in the $\mathrm{B}_{\mathrm{PV}}$ section. To convert this subsurface volume of $\mathrm{KR}_{\mathrm{RES}}$ to a storage resource, the total volume is reduced by a storage efficiency value. The storage efficiency distribution for the oil and gas reservoirs used for this resource estimation will be the same as the buoyant storage efficiency values. The known recovery replacement storage resource $\left(\mathrm{KRR}_{\mathrm{SR}}\right)$ is determined by multiplying the $\mathrm{KR}_{\mathrm{RES}}$ by the density of $\mathrm{CO}_{2}$. A probabilistic distribution of the density of $\mathrm{CO}_{2}$ is calculated by the assessment team based on the upper and lower depth boundaries of the storage formation, temperature and pressure gradients appropriate for the area, and an equation of state for $\mathrm{CO}_{2}$. 


$$
K R R_{S R}=\left(K R_{R E S} \times B_{S E}\right) \times \rho \mathrm{CO}_{2}
$$

where $\mathrm{KR}_{\mathrm{RES}}$

$\mathrm{B}_{\mathrm{SE}}$ $\rho \mathrm{CO}_{2}$

is the known recovery corrected to a volume at subsurface conditions (volume), calculated in equation (2);

is the buoyant storage efficiency (fraction); and

is the density of $\mathrm{CO}_{2}$ (mass/volume).

With this step, the calculation for $\mathrm{KRR}_{\mathrm{SR}}$ is complete.

\subsection{Final Assessment Products}

The final assessment products will include illustrations and storage resource values. The final assessment of each SAU will include illustrations of structure, depth below the surface, and isopach maps as well as well penetration cell maps for each SAU. The cell maps will include the total number of well penetrations through the SF per square mile grid blocks. The storage resource values will be reported as the F95 (denotes a 95 percent chance that the amount reported will be present within the SAU); other fractiles are defined similarly), $\mathrm{F} 50, \mathrm{~F} 5$, and mean values of the mass of $\mathrm{CO}_{2}$ retained in the:

1. The total buoyant storage fraction; in other words, the buoyant trapping storage resource $\left(\mathrm{B}_{\mathrm{SR}}\right)$.

2. The residual storage fractions; in other words, the residual trapping storage resource $\left(\mathrm{R}_{\mathrm{SR}}\right)$, with classes 1,2 , and 3 reported separately $\left(\mathrm{R} 1_{\mathrm{SR}}, \mathrm{R} 2_{\mathrm{SR}}, \mathrm{R} 3_{\mathrm{SR}}\right)$.

3. The total storage formation resource; in other words, the technically accessible storage resource $\left(\mathrm{TA}_{\mathrm{SR}}\right)$.

4. The oil and gas reservoir storage; in other words, the known recovery replacement storage resource $\left(\mathrm{KRR}_{\mathrm{SR}}\right)$.

\section{An Example of the Storage Resource Calculation}

\subsection{Data Sources}

Geologic and assessment models are built on geologic framework studies from USGS oil and gas assessments. Such basin studies have resulted in structure and thickness models, stratigraphic columns, cross sections, and general knowledge of the geology that are used to identify the SAU. Additional comprehensive data searches from published and unpublished work by the USGS, State geological surveys, petroleum industry producer associations or agencies, commercial databases, and the general literature are conducted to obtain additional information for use by assessment geologists. Quantitative data at the oil and gas reservoir level, including composition, porosity, permeability, size, thickness, depths, lithology, drive mechanism, and production data, are available in a commercial database, "Significant Oil and Gas Fields of the United States" (Nehring Associates, Inc., 2008). The USGS $\mathrm{CO}_{2}$ storage resource assessment calculations include data from fields with at least 0.5 million barrels of oil equivalent (MMBOE). This minimum size is the same as that used by the USGS NOGA methodology as well as Nehring Associates, Inc. Maintaining the same volume limits as NOGA ensures the applicability of their undiscovered petroleum volumes for use in this assessment's calculations.

Data at the individual well level, including location, producing formation, formation tops, bottom hole pressures, perforation zones, and production of oil, gas, and water, were obtained from the 
commercial database, "PI/Dwights PLUS on CD" (IHS Inc., 2008a). Volumes of produced and injected water, oil, gas, and natural gas liquid, along with core sample measurements, were obtained from a separate IHS database called "PIDM 2.5" (IHS Inc., 2008b).

Nehring Associates, Inc., and IHS Inc., commercial databases are all proprietary. No data from these datasets, whether tabular or spatial in nature, will be published or made available to the public in any way throughout the assessment process. Derivative aggregations of data and analytical results that are not related to specific wells, reservoirs, or fields will be included in assessment publications.

\subsection{An Example-The Tensleep Sandstone Storage Assessment Unit}

The Pennsylvanian-Permian Tensleep Sandstone of the Wind River Basin, Wyoming, was selected to demonstrate the USGS methodology for assessing $\mathrm{CO}_{2}$ storage resources. The Tensleep Sandstone provides a straightforward test case as a storage assessment unit because it lies within a mature petroleum basin with available production data, has a broadly uniform thickness, and is discussed at length in the literature. The assessment focused on the upper 100 feet $(30 \mathrm{~m})$, approximately, of the Tensleep Sandstone where petroleum is produced from a massive eolian sandstone unit, which has high porosity and permeability values. Furthermore, the recent assessment of the petroleum potential of the Wind River Basin (Kirschbaum and others, 2007) provided up-to-date data and interpretations that are highly useful for completing a $\mathrm{CO}_{2}$ storage capacity assessment. However, because the formation waters of the Tensleep Sandstone SAU have TDS concentrations below 10,000 ppm (mg/L), this particular SAU cannot be used for sequestration under current EPA guidelines. Therefore, storage resource values presented for this example are for illustrative purposes only.

\subsection{Form Inputs}

This section describes what information needs to be entered on the input data form (appendix A) for the Tensleep Sandstone SAU example. The first section of the SF assessment model form (Identification Information) includes a description of the SAU, as well as a section for notes from the assessment geologist. The characteristics of the SAU are entered in the second section of the form (Characteristics of the Storage Assessment Unit (SAU)). The SAU was created following the guidelines outlined in section 2.3.1 using GIS software with datasets from Kirschbaum and others (2007), Fox and others (1975), Nehring Associates, Inc. (2008), and IHS Inc. (2008a). A map of the SAU with structure contours is presented in figure 4. 


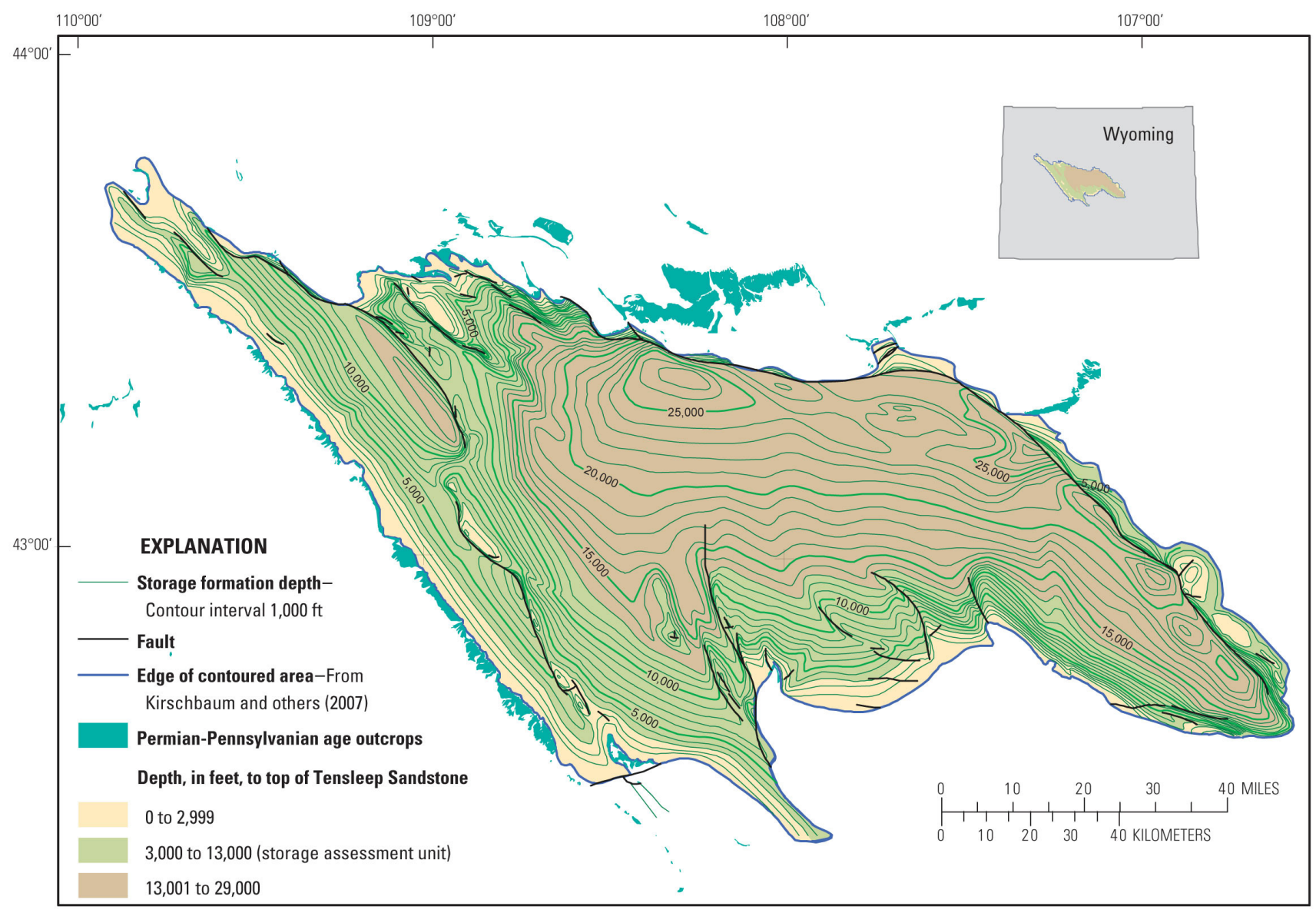

Figure 4. The Tensleep Sandstone storage assessment unit in the Wind River Basin, Wyoming, is confined to the parts of the formation where the top of the unit is at least 3,000 $\mathrm{ft}(914 \mathrm{~m})$ below land surface and the bottom of the unit is no deeper than $13,000 \mathrm{ft}(3,962 \mathrm{~m})$. Figure modified from Kirschbaum and others (2007).

Storage formation pore volume $\left(\mathrm{SF}_{\mathrm{PV}}\right)$ is the product of three inputs. First, GIS software was used to calculate the area of the Tensleep Sandstone SAU. A mode value of 1,400,000 was entered on line 4 of the form, and values were entered for the minimum and maximum areas $(1,300,000$ and $1,400,000$, respectively) to account for the relatively limited uncertainty in the area calculation. The mean net porous interval thicknesses of 80,100 and 120 feet $(\sim 24,30$, and $37 \mathrm{~m})$ inputs were based on data from Fox and others (1975). Mean porosity distribution values were also based on data from Fox and others (1975); however, reservoir values from the Nehring database (Nehring Associates, Inc., 2008) were also used.

Buoyant trapping pore volume is determined by the $\mathrm{CO}_{2}$ assessment team in conjunction with the assessment geologist using a variety of sources of data. Known recovery production volumes from reservoirs within the Tensleep Sandstone SAU from Nehring Associates, Inc. (2008), were converted to reservoir conditions using appropriate ranges of formation volume factors for both oil and gas (Beggs, 1987; Garb and Smith, 1987) (see section 3.5). A value of $190 \mathrm{MMbbl}$ was entered as the minimum buoyant trapping pore volume. USGS NOGA results were scaled proportionally to the SAU size and added to the minimum $\mathrm{B}_{\mathrm{PV}}$ to choose a mode $\mathrm{B}_{\mathrm{PV}}$. Published mean undiscovered oil and gas assessment figures from Kirschbaum and others (2007) were modified using values determined from past 
production to isolate Tensleep Sandstone production only. Those volumes were scaled to account for the areal discrepancy between the boundaries of the NOGA assessment unit (Kirschbaum and others, 2007) and the SAU (fig. 4). A volume, at reservoir conditions, of $15 \mathrm{MMbbl}$ was calculated and added to the minimum of $190 \mathrm{MMbbl}$ to produce the median of $205 \mathrm{MMbbl}$.

For this example, a maximum $B_{P V}$ value was chosen using a volumetric calculation method similar to that used for $\mathrm{SF}_{\mathrm{PV}}$, but for a much smaller area. The areas of potential enclosures, both dry traps and the water legs of existing fields, were determined from structure contour maps to be approximately 2.5 percent of the SAU area. A value of 4,100 MMbbl, which approximates 2.5 percent of the $\mathrm{SF}_{\mathrm{PV}}$, was used as the maximum input for $\mathrm{B}_{\mathrm{PV}}$. A log normal distribution is used for $\mathrm{B}_{\mathrm{PV}}$ in the probabilistic calculations.

Injectivity category allotment is the only input required for the residual trapping storage resource. Graphs of permeability information from Fox and others (1975) indicate that the majority of the porous interval in the Tensleep Sandstone has permeability values between 1 millidarcy (mD) and 1 Darcy (D). Only a small percentage of the formation exhibits permeability values indicative of class 1 or class 3 categories.

The storage efficiency values used in this example are included to facilitate understanding of the resource calculations but are not provided on the form and are not an input chosen by the assessment geologist. As stated in section 3.2, buoyant trapping storage efficiencies $\left(\mathrm{B}_{\mathrm{SE}}\right)$ used in this methodology are based on experimentally derived relative permeability curves (Bennion and Bachu, 2005, 2008; Burton and others, 2008). In this example, values of 10 percent, 30 percent, and 60 percent were used for minimum, mode, and maximum $\mathrm{B}_{\mathrm{SE}}$. Storage efficiencies associated with residual trapping are poorly understood as mentioned in section 3.3. Inputs based on modeled values for sandstones from Gorecki and others (2009) modified by the injectivity and mobility of $\mathrm{CO}_{2}$ and the likelihood of residual trapping were used in this example. Values of 1 percent, 5 percent, and 7 percent for $\mathrm{R} 1_{\mathrm{SE}}, 1$ percent, 7 percent, and 15 percent for $\mathrm{R} 2_{\mathrm{SE}}$, and 0 percent, 0 percent, and 7 percent for $\mathrm{R} 3_{\mathrm{SE}}$ were used for minimum, mode, and maximum residual storage efficiency.

The last three sections of the form cover the allocation of $\mathrm{CO}_{2}$ storage resource by area for Federal, State, tribal, and private lands, and other classifications. Areal allocations were designated using maps of these lands; however, volume percentage allocations are derived from the geologic information collected and analyzed throughout the example assessment project. Some areas or land types contain more or less of the resource than would be determined with a straight areal allocation.

\subsection{Results}

Results from the probabilistic assessment indicate that the Tensleep Sandstone SAU has mean $\mathrm{CO}_{2}$ storage values of 13.4 million short tons (mst) (12.2 million metric tons (Mt)) of buoyant trapping storage resource, $36.9 \mathrm{mst}(33.5 \mathrm{Mt})$ of residual trapping class 1 storage resource, 1,179 mst (1,070 Mt) of residual trapping class 2 storage resource, $19.9 \mathrm{mst}(18.0 \mathrm{Mt})$ of residual trapping class 3 storage resource, and 1,244 mst (1,129 Mt) of technically accessible storage resource (table 1). In the Tensleep Sandstone, storage resources based on known recovery volumes are $7.6 \mathrm{mst}(6.9 \mathrm{Mt})$ of $\mathrm{CO}_{2}($ table 2$)$. 
Table 1. Storage resource values of $\mathrm{CO}_{2}$ for five different classifications within the Tensleep Sandstone storage assessment unit.

[mst, million short tons; Mt, million metric tons]

\begin{tabular}{ccccc}
\hline $\begin{array}{c}\text { Tensleep } \\
\text { Sandstone }\end{array}$ & F95 & F50 & F5 & Mean \\
\hline $\begin{array}{c}\text { Buoyant trapping } \\
\text { storage resource }\end{array}$ & $4.5 \mathrm{mst}(4.1 \mathrm{Mt})$ & $9.1 \mathrm{mst}(8.3 \mathrm{Mt})$ & $38.4 \mathrm{mst}(34.8 \mathrm{Mt})$ & $13.4 \mathrm{mst}(12.2 \mathrm{Mt})$ \\
$\begin{array}{c}\text { Residual trapping } \\
\text { class 1 storage } \\
\text { resource }\end{array}$ & $16.7 \mathrm{mst}(15.2 \mathrm{Mt})$ & $38.0 \mathrm{mst}(34.5 \mathrm{Mt})$ & $58.6 \mathrm{mst}(53.2 \mathrm{Mt})$ & $36.9 \mathrm{mst}(33.5 \mathrm{Mt})$ \\
$\begin{array}{c}\text { Residual trapping } \\
\text { class 2 storage } \\
\text { resource }\end{array}$ & $450 \mathrm{mst}(408 \mathrm{Mt})$ & $1,200 \mathrm{mst}(1,089 \mathrm{Mt})$ & $2,069 \mathrm{mst}(1,877 \mathrm{Mt})$ & $1,179 \mathrm{mst}(1,070 \mathrm{Mt})$ \\
$\begin{array}{c}\text { Residual trapping } \\
\text { class 3 storage } \\
\text { resource }\end{array}$ & $1.6 \mathrm{mst}(1.5 \mathrm{Mt})$ & $19.0 \mathrm{mst}(17.2 \mathrm{Mt})$ & $47.1 \mathrm{mst}(42.7 \mathrm{Mt})$ & $19.9 \mathrm{mst}(18.0 \mathrm{Mt})$ \\
$\begin{array}{c}\text { Technically } \\
\text { accessible } \\
\text { storage resource }\end{array}$ & $514 \mathrm{mst}(466 \mathrm{Mt})$ & $1,250 \mathrm{mst}(1,134 \mathrm{Mt})$ & $2,125 \mathrm{mst}(1,928 \mathrm{Mt})$ & $1,244 \mathrm{mst}(1,129 \mathrm{Mt})$ \\
\hline
\end{tabular}

Table 2. Storage resource values of $\mathrm{CO}_{2}$ for petroleum reservoirs in the Tensleep Sandstone storage assessment unit. [mst, million short tons; Mt, million metric tons]

\begin{tabular}{ccccc}
\hline $\begin{array}{c}\text { Tensleep } \\
\text { Sandstone }\end{array}$ & F95 & F50 & F5 & Mean \\
\hline $\begin{array}{c}\text { Known recovery } \\
\text { replacement } \\
\text { storage resource }\end{array}$ & $3.9 \mathrm{mst}(3.5 \mathrm{Mt})$ & $7.4 \mathrm{mst}(6.7 \mathrm{Mt})$ & $11.6 \mathrm{mst}(10.5 \mathrm{Mt})$ & $7.6 \mathrm{mst}(6.9 \mathrm{Mt})$ \\
\hline
\end{tabular}

\section{Conclusions}

This report describes a probabilistic methodology to assess the $\mathrm{CO}_{2}$ storage resource of geologic strata in sedimentary basins in the United States. The fully probabilistic method captures the uncertainty of (1) the geologic parameters which define the storage formation pore volume; (2) the fraction of that pore space in which $\mathrm{CO}_{2}$ will be retained; and (3) the mass of the $\mathrm{CO}_{2}$ retained in that pore volume. The resulting products created using this methodology include the storage resources, reported in mass of $\mathrm{CO}_{2}$, of (1) the entire storage formation; (2) the buoyant trapping and residual trapping within the storage formation; and (3) the storage within oil and gas reservoirs.

\section{Acknowledgments}

The authors thank USGS authors from previous versions of this methodology; Mark F. Becker, William N. Herkelrath, Yousif K. Kharaka, Christopher E. Neuzil, Sharon M. Swanson, Troy A. Cook, Timothy R. Klett, Philip H. Nelson, and Christopher J. Schenk. Thanks to Ronald R. Charpentier (USGS) for expert guidance and advice on developing probabilistic models and calculations. Substantial improvements and modifications to earlier versions could not have occurred without the assistance of reviews and meetings with the members of an external review panel (Stefan Bachu (Alberta Innovates-Technology Futures, Edmonton, Alberta, Canada), Charles Gorecki (Energy \& 
Environmental Research Center, University of North Dakota, Grand Forks, N. Dak.), Kenneth Hood (ExxonMobil Exploration Company, Houston Tex.), William Maze (ExxonMobil Upstream Research Company, Houston, Tex. - Chairman of the review committee), George Peridas (Natural Resource Defense Council, San Francisco, Calif.), Rusty Riese (BP Alternative Energy, Houston, Tex.), John Rupp (Indiana Geological Survey, Bloomington, Ind.), and Gary Teletzke (ExxonMobil Upstream Research Company, Houston, Tex) $)^{1}$. The content and presentation of this report benefited greatly from the technical reviews of Ronald R. Charpentier, Christopher J. Schenk, Laurie Burke, Phil Nelson, Troy Cook, and Lynn Tennyson. In the methodology development process, extensive collaboration was provided by the USGS Tertiary assessment team, especially Alex Karlsen, and the USGS Wind River Basin Province assessment team, in particular Mark Kirschbaum and Laura Roberts. Susan D. Hovorka and the Gulf Coast Carbon Center team at the Texas Bureau of Economic Geology provided data and helpful discussions on the potential for $\mathrm{CO}_{2}$ storage in the sediments of the Texas Gulf Coast. Eric Morrissey (USGS) was helpful in the redesign of several illustrations within the report. The authors thank Desiree Polyak (USGS) for her contributions to the project. The authors also wish to acknowledge the support of the USGS Enterprise Publishing Network.

\section{References Cited}

Ahlbrandt, T.S., and Klett, T.R., 2005, Comparison of methods used to estimate conventional undiscovered petroleum resources-World examples: Natural Resources Research, v. 14, no. 3, p. 187-210, doi:10.1007/s11053-005-8076-0 [may require subscription to access].

Bachu, S., 2003, Screening and ranking of sedimentary basins for sequestration of $\mathrm{CO}_{2}$ in geological media in response to climate change: Environmental Geology, v. 44, p. 277-289, doi:10.1007/s00254-003-0762-9 [may require subscription to access].

Bachu, Stefan, Bonijoly, Didier, Bradshaw, John, Burruss, Robert, Holloway, Sam, Christensen, N.P., and Mathiassen, O.M., 2007, $\mathrm{CO}_{2}$ storage capacity estimation-Methodology and gaps: International Journal of Greenhouse Gas Control, v. 1, p. 430-443, doi:10.1016/S1750-5836(07)00086-2 [may require subscription to access].

Beggs, H. Dale, 1987, Oil system correlations, in Bradley, H.B., ed., Petroleum Engineering Handbook: Richardson, Tex., Society of Petroleum Engineers, p. 22-1 to 22-22.

Bennion, Brant, and Bachu, Stefan, 2005, Relative permeability characteristics for supercritical $\mathrm{CO}_{2}$ displacing water in a variety of potential sequestration zones in the Western Canada Sedimentary Basin, in Society of Petroleum Engineers Annual Technical Conference and Exhibition, 9-12 October 2005, Dallas, Tex., 2005, Proceedings: Richardson, Tex., Society of Petroleum Engineers, paper SPE 95547, 15 p., doi:10.2118/95547-MS [may require subscription to access].

Bennion, D.B., and Bachu, Stefan, 2008, Drainage and imbibition relative permeability relationships for supercritical $\mathrm{CO}_{2}$ /brine and $\mathrm{H}_{2} \mathrm{~S} /$ brine systems in intergranular sandstone, carbonate, shale, and anhydrite rocks: Society of Petroleum Engineers Reservoir Evaluation and Engineering, v. 11, no. 3, p. 487-496, doi:10.2118/99326-PA [may require subscription to access].

\footnotetext{
${ }^{1}$ Public Law 110-140, Section 711(d)(2), mandated the establishment of "a panel of individuals with expertise in the matters described. . .composed of representatives of Federal agencies, institutions of higher education, nongovernmental organizations, State organizations, industry, and international geoscience organizations to review the methodology and comments received" on the carbon dioxide sequestration capacity assessment. The reviews provided by members of that panel were for technical purposes only and do not constitute an endorsement of the methodology presented herein by either the reviewers or their institutions.
} 
Benson, Sally, and Cook, Peter, 2005, Underground geological storage, chap. 5 of Intergovernmental Panel on Climate Change (IPCC), Working Group III, IPCC special report on carbon dioxide capture and storage (Metz, Bert, Davidson, Ogunlade, de Coninck, Heleen, Loos, Manuela, and Meyer, Leo, eds.): New York, Cambridge University Press, p. 195-276. (Also available at http://www.ipcc.ch/pdf/special-reports/srccs/srccs_chapter5.pdf.)

Bird, K.J., Charpentier, R.R., Gautier, D.L., Houseknecht, D.W., Klett, T.R., Pitman, J.K., Moore, T.E., Schenk, C.J., Tennyson, M.E., and Wandrey, C.R., 2008, Circum-Arctic resource appraisalEstimates of undiscovered oil and gas north of the Arctic Circle: U.S. Geological Survey Fact Sheet 2008-3049, 4 p. (Also available at http://pubs.usgs.gov/fs/2008/3049/.)

Bradshaw, John, 2004, Geological sequestration of $\mathrm{CO}_{2}$; Why, where and what role for geoscientists [abs.], in Boult, P.J., Johns, D.R., and Lang, S.C., eds., Eastern Australasian Basins Symposium II, 19-22d September 2004, Adelaide, South Australia [conference proceedings]: Sydney, Australia, Petroleum Exploration Society of Australia, p. 737.

Bradshaw, John, Boreham, Chris, and La Pedalina, Frank, 2005, Storage retention time of $\mathrm{CO}_{2}$ in sedimentary basins; Examples from petroleum systems, in Rubin, E.S., Keith, D.W., and Gilboy, C.F., eds., Proceedings of the 7th International Conference on Greenhouse Gas Control Technologies, 5-9 September 2004, Vancouver, Canada: Greenhouse Gas Control Technologies, v. 1, no. 4, p. 541550. (Also available at $h t t p: / / u r e g i n a . c a / g h g t 7 / P D F / p a p e r s / p e e r / 427 . p d f$ [may require subscription to access].)

Bradshaw, John, Bachu, Stefan, Bonijoly, Didier, Burruss, Robert, Holloway, Sam, Christensen, N.P., and Mathiassen, O.M., 2007, $\mathrm{CO}_{2}$ storage capacity estimation-Issues and development of standards: International Journal of Greenhouse Gas Control, v. 1, p. 62-68, doi:10.1016/S1750-5836(07)00027-8 [may require subscription to access].

Burruss, R.C., 2009, $\mathrm{CO}_{2}$ storage resources, reserves, and reserve growth; Toward a methodology for integrated assessment of the storage capacity of oil and gas reservoirs and saline formations: Energy Procedia, v. 1, no. 1, p. 2679-2683, doi:10.1016/j.egypro.2009.02.036 [may require subscription to access].

Burruss, R.C., Brennan, S.T., Freeman, P.A., Merrill, M.D., Ruppert, L.F., Becker, M.F., Herkelrath, W.N., Kharaka, Y.K., Neuzil, C.E., Swanson, S.M., Cook, T.A., Klett, T.R., Nelson, P.H., and Schenk, C.J., 2009, Development of a probabilistic assessment methodology for evaluation of carbon dioxide storage: U.S. Geological Survey Open-File Report 2009-1035, 81 p., accessed May 12, 2010, at $h t t p: / / p u b s . u s g s . g o v / o f / 2009 / 1035 /$.

Burton, McMillan, Kumar, Navanit, and Bryant, S.L., 2008, Time-dependent injectivity during $\mathrm{CO}_{2}$ storage in aquifers, in Symposium on Improved Oil Recovery, 20-23 April 2008, Tulsa, Okla., 2008, Proceedings: Richardson, Tex., Society of Petroleum Engineers, paper SPE 113937, 15 p., doi:10.2118/113937-MS [may require subscription to access].

Charpentier, R.R., and Klett, T.R., 2005, A Monte Carlo simulation method for the assessment of undiscovered, conventional oil and gas, chap. 21 of USGS Southwestern Wyoming Province Assessment Team, National Assessment of Oil and Gas Project; Petroleum systems and geologic assessment of oil and gas in the Southwestern Wyoming Province, Wyoming, Colorado, and Utah: U.S. Geological Survey Digital Data Series 69-D, 5 p., on CD-ROM. (Also available at http://pubs.usgs.gov/dds/dds-069/dds-069-d/.) 
Couples, G.D., 2005, Seals; The role of geomechanics, in Boult, Peter, and Kaldi, John, eds., Evaluating fault and cap rock seals: American Association of Petroleum Geologists Hedberg Series, no. 2, p. 87-108, doi:10.1306/1060758H21906 [may require subscription to access].

Craft, B.C., and Hawkins, M.F, 1991, Applied petroleum reservoir engineering (2d ed., revised by R.E. Terry): Englewood Cliffs, N.J., Prentice Hall, 431 p.

Dandekar, A.Y., 2006, Petroleum reservoir rock and fluid properties: New York, Taylor and Francis Group, $460 \mathrm{p}$.

Fox, J.E., Lambert, P.W., Mast, R.F., Nuss, N.W., and Rein, R.D., 1975, Porosity variation in the Tensleep and its equivalent the Weber Sandstone, western Wyoming-A log and petrographic analysis, in Bolyard, D.W., ed., Deep drilling frontiers of the central Rocky Mountains: Rocky Mountain Association of Geologists Guidebook, p. 185-216.

Frailey, S.M., and Finley, R.J., 2009, Classification of $\mathrm{CO}_{2}$ geologic storage-Resource and capacity: Energy Procedia, v. 1, no. 1, p. 2623-2630, doi:10.1016/j.egypro.2009.02.029 [may require subscription to access].

Garb, F.A., and Smith, G.L., 1987, Estimation of oil and gas resources, in Bradley, H.B., ed. Petroleum Engineering Handbook: Richardson, Tex., Society of Petroleum Engineers, p. 40-1 to 40-38.

Gautier, D.L., Bird, K.J., Charpentier, R.R., Grantz, Arthur, Houseknecht, D.W., Klett, T.R., Moore, T.E., Pitman, J.K., Schenk, C.J., Schuenemeyer, J.H., Sorensen, Kai, Tennyson, M.E., Valin, Z.C., and Wandrey, C.J., 2009, Assessment of undiscovered oil and gas in the Arctic: Science, v. 324, no. 5931, p. 1175-1179, doi:10.1126/science.1169467 [may require subscription to access].

Gorecki, C.D., Sorensen, J.A., Bremer, J.M., Knudsen, D.J., Smith, S.A., Steadman, E.N., and Harju, J.A., 2009, Development of storage coefficients for determining the effective $\mathrm{CO}_{2}$ storage resource in deep saline formations, in Society of Petroleum Engineers International Conference on $\mathrm{CO}_{2}$ Capture, Storage, and Utilization, 2-4 November 2009, San Diego, Calif., 2009, Proceedings: Richardson, Tex., Society of Petroleum Engineers, no. 126444, doi:10.2118/126444-MS [may require subscription to access].

Hermanrud, Christian, Nordgård Bolås, H.M., and Tiege, G.M.G., 2005, Seal failure related to basinscale processes, in Boult, Peter, and Kaldi, John, eds., Evaluating fault and cap rock seals: American Association of Petroleum Geologists Hedberg Series, no. 2, p. 13-22, doi:10.1306/1060753H23159 [may require subscription to access].

IHS Inc., 2008a, PI/Dwights PLUS on CD, v. 18, issue 7-8: Englewood, Colo., IHS Inc.

IHS Inc., 2008b, PIDM 2.5: Englewood, Colo., IHS Inc.

Juanes, Ruben, Spiteri, E.J., Orr, F.M., Jr., and Blunt, M.J., 2006, Impact of relative permeability hysteresis on geological $\mathrm{CO}_{2}$ storage: Water Resources Research, v. 42, W12418, doi:10.1029/2005WR004806 [may require subscription to access].

Juanes, Ruben, MacMinn, C.W., and Szulczewski, M.L., 2010, The footprint of the $\mathrm{CO}_{2}$ plume during carbon dioxide storage in saline aquifers; Storage efficiency for capillary trapping at the basin scale: Transport in Porous Media, v. 82, no. 1, p. 19-30, doi:10.1007/s 11242-009-9420-3 [may require subscription to access].

Kirschbaum, M.A., Lillis, P.G., and Roberts, L.N.R., 2007, Geologic assessment of undiscovered oil and gas resources in the Phosphoria Total Petroleum System of the Wind River Basin Province, Wyoming, chap. 3 of USGS Wind River Basin Province Assessment Team, National Assessment of Oil and Gas Project; Petroleum systems and geologic assessment of oil and gas in the Wind River 
Basin Province, Wyoming: U.S. Geological Survey Digital Data Series DDS-69-J, 27 p., on CDROM. (Also available at http://pubs.usgs.gov/dds/dds-069/dds-069-j/.)

Klett, T.R., Schmoker, J.W., Charpentier, R.R., Ahlbrandt, T.S., and Ulmishek, G.Fr., 2005, Glossary, chap. 25 of USGS Southwestern Wyoming Province Assessment Team, National Assessment of Oil and Gas Project; Petroleum systems and geologic assessment of oil and gas in the Southwestern Wyoming Province, Wyoming, Colorado, and Utah: U.S. Geological Survey Digital Data Series 69-D, 3 p., on CD-ROM. (Also available at http://pubs.usgs.gov/dds/dds-069/dds-069-d/.)

Lucier, Amie, and Zoback, Mark, 2008, Assessing the economic feasibility of regional deep saline aquifer $\mathrm{CO}_{2}$ injection and storage-A geomechanics-based workflow applied to the Rose Run sandstone in eastern Ohio, USA: International Journal of Greenhouse Gas Control, v. 2, no. 2, p. 230-247, doi:10:1016/j.ijggc.2007.12.002 [may require subscription to access].

National Institute of Standards, 2009, Thermophysical properties of fluid systems models: NIST standard reference database number 69, accessed January 13, 2009, at http://webbook.nist.gov/chemistry/.

Nehring Associates, Inc., 2008, Significant oil and gas fields of the United States database [includes data current as of December 31, 2006]: Colorado Springs, Colo., Nehring Associates, Inc.

Public Law 110-140, 2007, Energy Independence and Security Act of 2007, U.S. Government Printing Office, accessed May 12, 2010, at http://frwebgate.access.gpo.gov/cgi-bin/ getdoc.cgi?dbname=110_cong_public_laws\&docid=f:publ140.110.pdf.

Saadatpoor, Ehsan, Bryant, S.L., and Sepehrnoori, Kamy, 2010, New trapping mechanism in carbon sequestration: Transport in Porous Media, v. 82, no. 1, p. 3-17, doi:10.1007/s11242-009-9446-6 [may require subscription to access].

Schmoker, J.W., and Klett, T.R., 2005, U.S. Geological Survey assessment concepts for conventional petroleum accumulations, chap. 19 of USGS Southwestern Wyoming Province Assessment Team, National Assessment of Oil and Gas Project; Petroleum systems and geologic assessment of oil and gas in the Southwestern Wyoming Province, Wyoming, Colorado, and Utah: U.S. Geological Survey Digital Data Series 69-D, 6 p., on CD-ROM. (Also available at http://pubs.usgs.gov/dds/dds069/dds-069-d/.)

Skerlec, G.M., 1999, Evaluating top and fault seal, in Beaumont, E.A., and Foster, N.H., eds., Exploring for oil and gas traps, v. 3 of Treatise of petroleum geology; Handbook of petroleum geology: Tulsa, Okla., American Association of Petroleum Geologists, p. 10.3-10.94. (Also available at $h$ ttp://search.datapages.com/data/specpubs/beaumont/ch10/ch10.htm? $q=\% 2$ Bauthor\%3Askerlec [may require subscription to access].)

U.S. Department of Energy, National Energy Technology Laboratory, 2008, Carbon sequestration atlas of the United States and Canada (2d ed.; Atlas II): 142 p., accessed May 12, 2010, at http://www.netl.doe.gov/technologies/carbon_seq/refshelf/atlasII/2008\%20ATLAS_Introduction.pdf.

U.S. Environmental Protection Agency, 2008, Federal requirements under the underground injection control (UIC) program for carbon dioxide $\left(\mathrm{CO}_{2}\right)$ geologic sequestration (GS) wells: Washington, D.C., U.S. Environmental Protection Agency, proposed rule, accessed January 14, 2009, at http://www.epa.gov/fedrgstr/EPA-WATER/2008/July/Day-25/w16626.htm.

U.S. Environmental Protection Agency, 2009, Safe Drinking Water Act (SDWA): Washington, D.C., U.S. Environmental Protection Agency Web site, accessed January 14, 2009, at http://www.epa.gov/ogwdw/sdwa/index.html. 
van der Meer, Bert, and Egberts, Paul, 2008, Calculating subsurface $\mathrm{CO}_{2}$ storage capacities: The Leading Edge, v. 27, no. 4, p. 502-505, doi:10.1190/1.2907182 [may require subscription to access].

Wiprut, David, and Zoback, M.D., 2000, Fault reactivation and fluid flow along a previously dormant normal fault in the northern North Sea: Geology, v. 28, no. 7, p. 585-598, doi:10.1130/0091-7613 [may require subscription to access]. 


\section{Glossary}

barrels of oil equivalent (BOE) A unit of petroleum volume in which the gas part is expressed in terms of its energy equivalent in barrels of oil. For this assessment, the energy equivalent (not the volume equivalent) of 6,000 cubic feet of natural gas equals 1 barrel of oil equivalent (Klett and others, 2005). brine Water having a salinity higher than that of average seawater, that is, more than 35,000 parts per million (milligrams per liter) total dissolved solids.

buoyancy Upward force on one phase (for example, a fluid) produced by the surrounding fluid (for example, a liquid or a gas) in which it is fully or partially immersed, caused by differences in density.

buoyant trapping $\mathrm{CO}_{2}$ in communication across pore space creating a column that is held in place by a top and lateral seal, either a seal formation or a sealing fault.

buoyant trapping pore volume (BPv) A geologically determined, probabilistic-distribution of the volume fraction of the storage formation that can store $\mathrm{CO}_{2}$ by buoyant trapping. This distribution minimum is typically defined by existing plus forecast undiscovered oil and gas production volumes. The maximum is probabilistically calculated from distributions of geologic parameters describing the known trapping structures within the storage formation.

buoyant trapping storage efficiency (BSE) A distribution of efficiency values that describes the fraction of buoyant trapping that can occur within a volume of porous media.

buoyant trapping storage resource (BSR) Mass of $\mathrm{CO}_{2}$ retained in the storage formation by buoyant trapping.

buoyant trapping storage volume (Bsv) Volume of $\mathrm{CO}_{2}$ retained in the storage formation by buoyant trapping.

capillary entrance pressure The pressure necessary to displace a wetting fluid from a porous medium by a nonwetting phase (for example, displacing water with gas or mercury). The surface tension between the phases is a function of the radius of curvature of the interface between the phases, causing capillary entrance pressures to increase as the diameter of the pores and pore throats decreases. Very fine grained rocks, like mudstones, have very high capillary entrance pressures allowing them to be barriers to flow (seals) for nonwetting fluids, such as oil, gas, and supercritical $\mathrm{CO}_{2}$.

capillary force Capillary forces in a petroleum reservoir are the result of the combined effect of surface and interfacial tensions, pore size, geometry, and wetting characteristics of a given system (Dandekar, 2006, p. 145).

carbon dioxide plume The subsurface extent, in three dimensions, of an injected carbon dioxide stream.

column height The thickness defined by the highest and lowest levels within the strata where the $\mathrm{CO}_{2}$ phase is continuously connected. This column is held in place by top and lateral seals, and its thickness is controlled by the geometry of the closure and (or) the seal adequacy.

enhanced oil recovery Any process of tertiary oil recovery that follows recovery using natural reservoir pressure (primary recovery) and water flooding (secondary recovery). Common methods include steam-flooding for heavy oil, polymer and surfactant flooding, and $\mathrm{CO}_{2}$ miscible gas flooding.

gas:oil ratio (GOR) Ratio of gas to oil (in cubic feet per barrel) in a hydrocarbon accumulation. This ratio is calculated by using volumes of gas and oil at surface conditions. 
gas reservoir A hydrocarbon accumulation composed primarily of gas, defined by the USGS as an accumulation having a gas:oil ratio of 20,000 cubic feet per barrel or greater.

geologic storage of $\mathrm{CO}_{2}$ The long-term retention of carbon dioxide in subsurface geologic formations. injectivity The rate and pressure at which fluids can be pumped into the rock without fracturing the formation. Although injectivity is typically reported as a rate, this methodology addresses this requirement by using permeability values to divide the residual storage component of the storage formation into three classes.

known recovery production volumes (KR) The cumulative petroleum production and proved reserves for a given reservoir.

known recovery replacement storage resource (KRRsR) The storage resource calculated from known recovery production volumes.

minimum size The lower limit for inclusion of oil and gas field information in assessment calculations. Volumetric data from accumulations with less than 0.5 million barrels of oil equivalent total production are not included in any of the calculations in this methodology.

National Oil and Gas Assessment (NOGA) U.S. Geological Survey National Oil and Gas Assessment, described at http://energy.cr.usgs.gov/oilgas/noga/.

net porous thickness $\left(\mathrm{T}_{\mathrm{PI}}\right)$ Defined in this methodology as the stratigraphic thickness of the storage formation with a porosity of 8 percent or higher.

oil reservoir A hydrocarbon accumulation composed primarily of oil, defined by the USGS as an accumulation having a gas:oil ratio of less than 20,000 cubic feet per barrel.

original oil in place The total in-place volume of oil within a hydrocarbon reservoir or field, or within a larger region such as a basin or country, prior to the onset of production. The volume of the oil is reported at surface conditions, not reservoir conditions.

permeability (k) A measure of the ability of a rock to transmit fluids, controlled by pore size and pore throat geometry. Typically reported in Darcy units.

porosity $(\phi)$ The part of a rock that is occupied by voids or pores. Pores can be connected by passages called pore throats, which allow for fluid flow, or pores can be isolated and inaccessible to fluid flow. Porosity is typically reported as a volume, fraction, or percentage.

pressure gradient The change in pore pressure per unit depth, typically in units of pound-force per square inch per foot or kilopascals per meter.

residual trapping Discrete droplets, blobs, or ganglia of $\mathrm{CO}_{2}$ as a nonwetting phase, essentially immiscible with the wetting fluid, trapped within individual pores where the capillary forces overcome the buoyant forces.

residual trapping class 1 (R1) Residually trapped storage formation rock having a permeability of greater than 1 Darcy.

residual trapping class 2 (R2) Residually trapped storage formation rock having a permeability of greater than 1 millidarcy and less than than 1 Darcy.

residual trapping class 3 (R3) Residually trapped storage formation rock having a permeability of less than 1 millidarcy.

residual trapping pore volume $\left(R_{\mathrm{PV}}\right)$ A calculated value equal to the storage formation pore volume $\left(\mathrm{SF}_{\mathrm{PV}}\right)$ minus the buoyant trapping pore volume $\left(\mathrm{B}_{\mathrm{PV}}\right)$. The value represents the pore volume within the 
storage formation that can be used to store $\mathrm{CO}_{2}$ by residual trapping; it is calculated during iterations of the Monte Carlo simulator after a value from the buoyant trapping pore volume distribution is chosen.

residual trapping storage efficiency ( $R_{S E}$ ) A distribution of efficiency values that describes the fraction of residual trapping that can occur within a volume of porous media.

residual trapping storage resource ( $\left.R_{S R}\right)$ The mass of $\mathrm{CO}_{2}$ retained in the storage formation by residual trapping.

residual trapping storage volume (Rsv) The volume of $\mathrm{CO}_{2}$ retained in the storage formation by residual trapping.

salinity A measurement of the water properties determined by the total dissolved solids, generally reported in parts per million or milligrams per liter.

seal formation The confining rock unit within the storage assessment unit. The seal formation is a rock unit that sufficiently overlies the storage formation and has a capillary entrance pressure low enough to effectively inhibit the upward buoyant flow of $\mathrm{CO}_{2}$.

seal A geologic feature that inhibits the mixing or migration of fluids and gases between adjacent geologic units. Typically a rock unit or a fault; it can be a top seal, inhibiting upward flow of buoyant fluids, or a lateral seal, inhibiting the lateral flow of buoyant fluids.

storage assessment unit (SAU) A mappable volume of rock that includes the storage formation, a reservoir flow unit for $\mathrm{CO}_{2}$ storage, and a regional seal formation.

storage formation (SF) The reservoir component of the storage assessment unit. The sedimentary rock layers that are saturated with formation water with total dissolved solids greater than 10,000 parts per million (milligrams per liter). In the $\mathrm{CO}_{2}$ assessment methodology, the storage formation resource calculation is the main resource calculation and consists of two parts, a buoyant trapping resource and a residual trapping resource.

storage formation pore volume (SF $\mathrm{pv}$ ) The available pore space in the storage formation calculated from area, thickness of the net porous interval, and porosity. This value is used in the calculation of residual trapping pore volume $\left(\mathrm{R}_{\mathrm{PV}}\right)$.

supercritical $\mathrm{CO}_{2}$ Carbon dioxide is in a supercritical fluid state when both the temperature and pressure exceed the critical temperature of $88^{\circ} \mathrm{F}\left(31^{\circ} \mathrm{C}\right)$ and pressure of 74 bars $(7,400$ kilopascal $)$ at which liquid and vapor $\mathrm{CO}_{2}$ can no longer coexist.

technically accessible storage resource (TASR) The $\mathrm{CO}_{2}$ storage resource that may be available for $\mathrm{CO}_{2}$ injection and storage estimated by using present-day geologic and hydrologic knowledge of the subsurface and engineering practices. Analogous to the term "technically recoverable resource" used in USGS oil and gas assessments.

technically accessible storage volume (TAsv) The $\mathrm{CO}_{2}$ storage volume that may be available for $\mathrm{CO}_{2}$ injection and storage estimated by using present-day geologic and hydrologic knowledge of the subsurface and engineering practices.

total dissolved solids (TDS) Synonymous with salinity; see salinity.

trapping The physical and geochemical processes by which injected $\mathrm{CO}_{2}$ is retained in the subsurface. 


\section{Appendix A. Assessment Input Forms}

\section{Storage Formation (SF) Assessment Method: Input Data Form}

The input sections for the storage formation form are described in section 4.3. 


\section{STORAGE FORMATION (SF) ASSESSMENT MODEL: INPUT DATA FORM}

IDENTIFICATION INFORMATION

Assessment Geologist:

Region:

Province:

Storage Assessment Unit (SAU):

SAU Relationship to NOGA AU:

Based on Data as of:
USGS

North America

Wind River Basin

Tensleep Sandstone

NOGA AU Tensleep-Park City Conventional Oil and Gas

Nehring Associates, Inc., 2008, data current through 2006;

Fox and others, 1975; Kirschbaum and others, 2007
Date:

Number:

Number:

Number:

$\begin{array}{r}5 \\ \hline 5035 \\ \hline S 50350101\end{array}$

Notes from Assessor:

CHARACTERISTICS OF THE STORAGE ASSESSMENT UNIT (SAU)

1) Storage formation depth (ft): $\quad$ minimum: 3,000

mode: 9,500

maximum: 13,000

2) Area of storage formation at depths between $3,000 \mathrm{ft}$ and $13,000 \mathrm{ft}$, or another interval (acres):

3) Total Storage Formation

Thickness $(3,000-13,000 \mathrm{ft})$ : minimum:

200

mode:

275

maximum:

600

STORAGE FORMATION PORE VOLUME (SFPV) PROBABILISTIC CALCULATION INPUTS
4) Mean SAU Area (line 2): minimum:
$1,300,000$
mode:
$1,400,000$
maximum:
$1,500,000$
5) Mean Thickness,
Net Porous Interval (ft):
minimum:
80
mode:
100
maximum:
120
6) Mean Porosity (fraction):
minimum:
0.1
mode:
0.15
maximum:
0.2

\section{BUOYANT TRAPPING PROBABILISTIC CALCULATION INPUTS}

7) Buoyant Trapping Pore Volume (MMbbl):

minimum:

190

mode:

205

maximum:

4,100

\section{RESIDUAL TRAPPING PROBABILISTIC CALCULATION INPUTS}

8) Injectivity Category Allotment (Sum $=1.0)$
a) Fraction with Class 1 Injectivity ( $>1 \mathrm{D})$
b) Fraction with Class 2 Injectivity $(1 \mathrm{mD}<\mathrm{k}<1 \mathrm{D})$
c) Fraction with Class 3 Injectivity $(<1 \mathrm{mD})$

Does the Class 1 fraction have a direct updip path to outcrop that may be a leakage risk? 
ALLOCATIONS OF THE SF TO STATES

Surface Allocations (uncertainty of a fixed value)

1)

\begin{tabular}{lcr} 
Wyoming & represents & 100 area \% of the SAU \\
Volume \% in entity & mode: & 100 \\
\hline
\end{tabular}

\section{ALLOCATIONS OF THE SF TO GENERAL LAND OWNERSHIPS Surface Allocations (uncertainty of a fixed value)}

1)

Federal Lands

Volume $\%$ in entity

Private Lands

Volume $\%$ in entity

3)

4)

5)

Tribal Lands

Volume \% in entity

Other Lands

Volume $\%$ in entity

WY State Lands

Volume $\%$ in entity

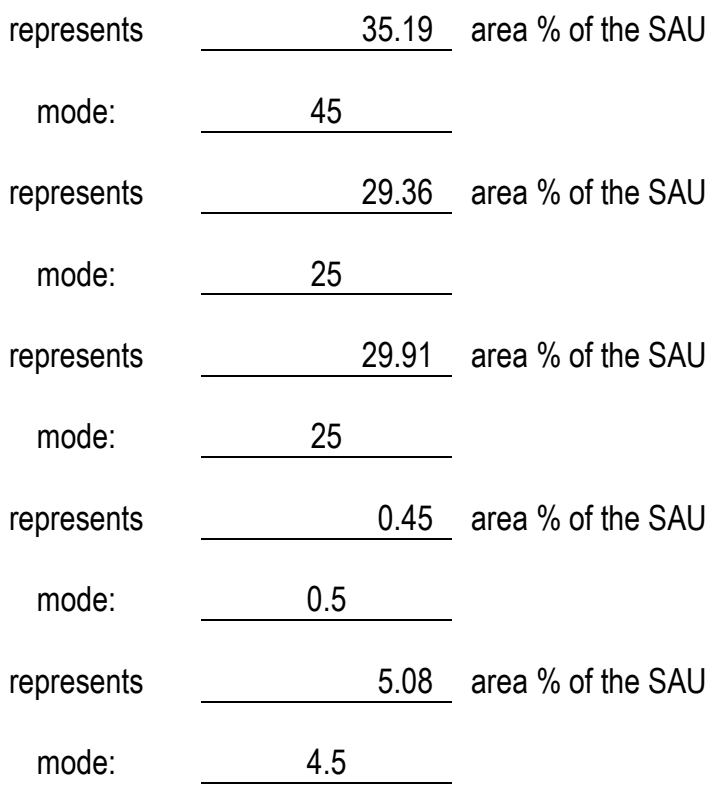

ALLOCATIONS OF THE SF TO CRITICAL LAND AREAS

Surface Allocations (uncertainty of a fixed value, does not total 100\%)

1)

Urban Lands

Volume $\%$ in entity

2) represents

$$
\text { minimum: }
$$
0.01

represents

minimum:

Volume $\%$ in entity
0 mode:

mode:

0.02 area $\%$ of the SAU

0.02

maximum:

0.04

0 area $\%$ of the SAU

0

maximum:

0 


\section{Appendix B. GIS Data Manipulations: Creating the SAU}

Creating SAU boundaries can be accomplished by using a number of different spatial calculation techniques and will be dependent on the data available. These instructions are intended for those with experience using GIS software and specifically raster calculations.

\section{B.1. Required Data Rasters}

[DepthTop] $=$ Raster of depth from surface to top of formation in feet with negative values.

[DepthBase] $=$ Raster of depth from surface to base of formation in feet with negative values.

[Isopach] $=$ Raster of the thickness of the reservoir formation in feet with positive values.

[WaterTDSLimit] $=$ Raster of the depth from surface to the potable/saline water contact at 10,000 ppm (mg/L) TDS in feet with negative values (see section 2.3.1 for discussion).

A [DepthTop] map and either an [Isopach] map or a [DepthBase] map is required initially. With a [DepthTop] and either the [Isopach] or [DepthBase], the final raster can be calculated. If elevations are relative to sea level, rather than the land surface, use a digital elevation model to add the appropriate elevation to the file. Directions below are specific to ESRI ArcGIS software. Other spatial analysis programs are suitable.

\section{B.2. Creation of Required Data Rasters}

To generate an [Isopach] map from [DepthTop] and [DepthBase], use ESRI ArcGIS Spatial Analyst raster calculator.

Raster Calculator: [Isopach] $=$ [DepthTop]-[DepthBase]

To generate a [DepthBase] map.

Raster Calculator: [DepthBase] $=$ [DepthTop]-[Isopach]

\section{B.3. Generating Storage Assessment Unit Extent and Modification of [DepthTop]}

Step 1: Select area of [DepthTop] that is at depths of between 3,000 and 13,000 ft.

Raster Calculator: [ExtentDepthTop3-13k] $=$ [DepthTop] $>=-13000$ AND [DepthTop] $<=-3000$

Step 2: Remove area of [DepthTop] that is not at depths of between 3,000 and 13,000 $\mathrm{ft}$.

Reclassify [ExtentDepthTop3-13k] so the removed area is "NoData."

Spatial Analyst Options: Set Analysis Mask to reclassified [ExtentDepthTop3-13k].

Raster Calculator: [DepthTop3-13k] = [DepthTop]

Step 3: Select area of [DepthTop3-13k] that is within potable water.

Raster Calculator: [ExtentDepthTop3-13kW] $=$ [DepthTop3-13k] $>$ [WaterTDSLimit]

Step 4: Remove area of [DepthTop3-13k] that is within potable water.

Reclassify [ExtentDepthTop3-13kW] so the removed area (potable water) is "NoData." Spatial Analyst Options: Set Analysis Mask to reclassified [ExtentDepthTop3-13kW].

Raster Calculator: [DepthTop3-13kW] = [DepthTop]

[DepthTop3-13kW] is the final product of this part of the calculation and is SAU area. 


\section{B.4. Isopach Generation and Modification}

Step 5: Spatial Analyst Options: Set Analysis Mask to [DepthTop3-13kW].

Raster Calculator: [Isopach3-13kW] = [DepthTop3-13kW] - $\max ([$ DepthBase], -13000)

[Isopach3-13kW] is the final product of this part of the calculation and represents the thickness of the storage formation from the top of the formation to whatever is shallower: the depth to base or 13,000 feet. 